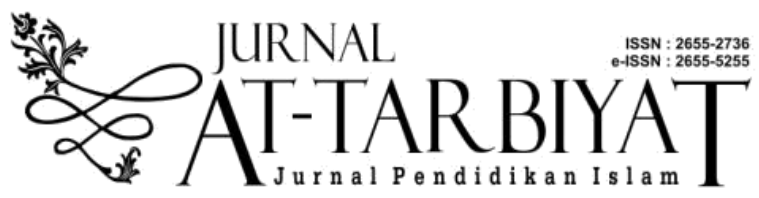

http://jurnal.staiannawawi.com/index.php/At-Tarbiyat

\title{
MANAJEMEN EKSTRAKURIKULER DALAM UPAYA PENGEMBANGAN DIRI SANTRI PONDOK PESANTREN AL-LUQMANIYYAH YOGYAKARTA
}

\author{
Ahmad Hinayatulohi \\ UIN Sunan Kalijaga Yogyakarta
}

\section{Abstrak}

Ekstrakrikuler merupakan wadah yang bisa digunakan untuk proses pengembangan diri santri di pondok pesantren. Pengelolaan yang baik terhadap ekstrakurikuler akan mengembangkan santri sesuai potensi kodratnya. Al-Luqmaniyyah Yogyakarta adalah pondok pesantren salaf yang memiliki manajemen ekstrakurikuler. Lahirnya bidang Pengembangan Sumber Daya Santri menjadi salah satu jawaban dalam mengatur ekstrakurikuler di pesantren Al-Luqmaniyyah. Penelitian ini menggunakan analisis deskriptif-kualitatif dengan Hasil penelitian menyebutkan bahwa konsep lahirnya ekstrakurikuler di pesantren Al-Luqmaniyyah adalah sebagai ajang pengembangan diri santri. Disisi lain tujuan yang ingin dicapai adalah sebagai wadah kegiatan santri di lingkungan pondok pesantren. Sehingga dengan adanya ekstrakurikuler, para santri tidak mencari kegiatan lain di luar lingkungan pesantren. Lahirnya bidang Pengembangan Sumber Daya Santri sebagai manajer dalam mengelola ekstrakurikuler yang ada. Penerapan manajemen ekstrakurikuler melalui empat tahap, yaitu perencanaan, pengorganisasian, pelaksanaan, dan pengawasan. Sedangkan hasil yang dicapai diantaranya, minat santri mengikuti esktrakurikuler bertambah setiap tahunnya, berkurangnya jumlah pelanggaran santri, pengembangan diri yang bertujuan akhir kepada kemandirian santri bisa terlihat melalui kemandirian emosi, intelektual, sosial, dan ekonomi

\section{Abstract}

Extracurricular is a media that can be used for the self-development process of santris in Pesantren (Islamic boarding schools). Good management of extracurricular activities will develop santri according to their natural potential. Al-Luqmaniyyah Yogyakarta is a salaf boarding school that has extracurricular management. The birth of the Santri Resource Development field is one of the answers in arranging 
extracurricular activities in Al-Luqmaniyyah Islamic boarding schools. This study uses descriptive-qualitative analysis with the results of the study stating that the concept of extracurricular birth in Al-Luqmaniyyah is a place for self-development of students. On the other hand the goal to be achieved is as a place for santri activities in Islamic boarding schools. So that with extracurricular activities, the santri did not look for other activities outside the pesantren environment. The birth of the Santri Resource Development field is as a manager in managing existing extracurricular activities. The application of extracurricular management through four stages, namely planning, organizing, implementing, and monitoring. Whereas the results achieved include, the interest of santri in following extracurricular activities increases every year, the reduction in the number of violations of santri, self-development whose ultimate goal is the independence of santri can be seen through emotional, intellectual, social, and economic independence.

Keyword: Management, Extracurricular, Pesantren (Islamic Boarding School)

\section{PENDAHULUAN}

Pendidikan merupakan usaha manusia untuk membina kepribadiannya sesuai dengan nilai-nilai di dalam masyarakat dan kebudayaan. ${ }^{1}$ Dengan adanya pendidikan nilai-nilai luhur suatu bangsa bisa terawat melalui generasi penerusnya. Beragam para ahli mendefinisikan pendidikan itu berbeda-beda, Ki Hajar Dewantara mengatakan bahwa pendidikan merupakan proses menuntun segala kekuatan kodrat anak agar mereka sebagai manusia dan anggota masyarakat bisa mencapai keselamatan dan kebahagian yang setinggi-tingginya. Dalam konteks ke-Indonesiaan definisi Pendidikan salah satunya tertuang dalam UU Nomor 20 tahun 2003 tentang Sistem Pendidikan Nasional dengan maksud intinya mengembangkan potensi diri dan semua kekuatan yang dimiliki peserta didik.

Oleh sebab itu, Semua jenis lembaga pendidikan baik pendidikan formal, informal maupun nonformal harus mampu mewujudkan cita-cita luhur pendidikan tersebut. Pesantren merupakan salah satu lembaga

\footnotetext{
${ }^{1}$ Hasbullah, Dasar-dasar Ilmu Pendidikan, (Jakarta: Rajawali Pers, 2011),
} hal. 1. 
pendidikan nonformal yang ada di Indonesia. Kehadiran lembaga ini, sudah sejak lama menjadi maskot pendidikan Indonesia dalam membentuk watak dan peradaban bangsa serta mencerdaskan kehidupan bangsa yang berbasis pada keimanan serta akhlak mulia, jauh sebelum undang-undang tentang Pendidikan Nasional dicetuskan. Sejarah mencatat bahwa pondok pesantren merupakan lembaga pendidikan tertua yang ada di Indonesia. ${ }^{2}$

Namun fenomena pendidikan saat ini, khususnya pesantren masih dipandang sebelah mata oleh sebagian masyarkat. Pandangan sebagai lembaga konservatif, eksklusif dan bahkan anti-perubahan masih melekat dinisbatkan terhadap lembaga pendidikan tertua itu. ${ }^{3}$ Apalagi jika melihat pondok pesantren yang bertipologi salaf, kelemahan-kelemahan akan semakin jelas terlihat, seperti pengelolaan masih tradisional, praktik manajemen berjalan sederhana dan berpola pada kebiasaan yang telah berlaku, belum memiliki wirausaha permanen, serta hampir semua pesantren salaf milik individu dan tidak bisa ditekan oleh kekuatan lain sehingga tugas kiai mejadi multifungsi yaitu sebagai guru, mubalig sekaligus manajer. ${ }^{4}$

Mengembalikan marwah pondok pesantren kepada fungsi pokok yang sebenarnya harus segera diwujudkan. Terobosan yang bisa dilakukan oleh pondok pesantren dalam mengembalikan fungsi pokoknya salah satunya adalah memberikan kebebasan kepada para santri untuk mengembangkan talenta mereka masing-masing baik yang berkenaan dengan pemikiran, teknologi, kewirausahaan maupun olahraga. Dan menyediakan wahana akulturasi diri di tengah-tengah masyarakat. ${ }^{5}$ Terobosan-terobosan tersebut bisa termuat dalam kegiatan ekstrakurikuler. Program ekstrakurikuler sekiranya mampu di manfaatkan serius oleh pondok pesantren sebagai sarana pengembangan diri para santrinya, namun di

${ }^{2}$ Nur Efendi, Manajemen Perubahan di Pesantren,(Sleman: Kalimedia, 2016), cet. 1. Hal. 1

${ }^{3}$ Ainurrofiq Dawam dan Ahmad Ta'arifin, Manajemen Madrasah Berbasis Pesantren, (Yogyakarta: ListafariskaPutra, 2005), hal. 6

${ }^{4}$ Hamdan Farehan dan Syarifuddin, Titik Tengkar Pesantren Resolusi Konflik Pesantren, (Yogyakarta: Pilar Religia, 2005), hal. 68.

${ }^{5}$ Ibid., hal 70 . 
sebagian pondok pesantren khususnya yang bertipologi tradisional kegitan ekstrakurikuler belum menjadi sorotan utama dalam proses pengembangan diri santri.

Kehadiran ekstrakurikuler di pondok pesantren akan bisa mewadahi dalam proses perkembangan santri dalam tambahnya ilmu pengetahuan secara umum serta mengetahui potensi diri yang dimilikinya. Hal itu senada dengan kedudukan santri dalam Undang-undang nomor 20 Tahun 2003 pasal 1 ayat 4 adalah "Anggota masyarakat yang berusaha mengembangkan potensi diri melalui proses pembelajaran pada jalur pendidikan baik pendidikan informal, pendidikan formal, maupun pendidikan non formal, pada jenjang Pendidikan dan jenis Pendidikan tertentu". ${ }^{6}$ Peraturan tersebut juga sama dengan landasan pengembangan diri dalam pendidikan secara umum yaitu mengacu pada potensi. Sedangkan dalam konsep pendidikan Islam mengacu fitrah, yang mempunyai arti kekuatan asli yang yang terpendam di dalam diri manusia yang dibawa sejak lahir. ${ }^{7}$

Pondok Pesantren Salaf Al-luqmaniyyah merupakan pondok pesantren salaf putra dan putri yang mengkaji ilmu Islam dengan menggunakan sumber Al-Quran, Hadits dan kitab-kitab klasik. Pesantren Alluqmaniyyah yang berada di kecamatan Umbulharjo, kota Yogyakarta, Provinsi Daerah Istimewa Yogyakarta. Awal perkembangannya, jumlah siswa tidak lebih dari dua puluh orang. Pada saat itu, Pondok Pesantren AlLuqmaniyyah diperuntukan khusus bagi para santri yang ingin menuntut ilmu agama, tanpa menempuh pendidikan formal. Perlahan Paradigma tersebut mulai dirubah dengan menerima para santri yang juga menempuh pendidikan formal di berbagai sekolah atau universitas di Yogyakarta. Perubahan yang dibuat akhirnya membuahkan hasil, banyak para santri yang berdatangan. Tahun demi tahun pesantren ini mulai diminati oleh para siswa dengan tujuan untuk menuntut dan memperdalam ilmu agama. Hingga saat

\footnotetext{
${ }^{6}$ Anonim, Undang-Undang Republik Indonesia Tahun 2003 ..., hal. 4.

${ }^{7}$ Arifin I dan Slamet, Kepemimpinan Kyai dalam Perubahan Manajemen Pondok Pesantren;Kasus Ponpes Tebu Ireng Jombang, (Yogyakarta: Aditya Media, 2010)
} 
ini tercatat sekitar 380 santri yang mondok dengan mayoritas adalah mahasiswa perguruan tinggi di dalam wilayah Yogyakarta.

Pondok Pesantren Al-Luqmaniyyah mempunyai kegiatan ekstrakurikuler dalam mengakomodir minat dan bakat para santrinya. Kehadiran ekstrakurikuler menjadi perhatian serius para pengurus di Pesantren Al-Luqmaniyyah, sehingga membentuk sebuah bidang khusus untuk mengelola ekstarkurikuler yang ada. Penelitian mengenai manajemen ekstrakurikuler dalam ranah pendidikan pesantren menjadi hal yang sangat penting dilakukan, ekstrakurikuler sebagai sarana bagi santri dalam mengembangkan diri menjadi manusia seutuhnya. selain itu penelitian ini sebagai langkah awal dalam menciptakan pengelolaan lembaga pesantren yang lebih baik secara keseluruhan, dan manajemen ekstrakuirkuler secara khusus.

\section{METODE PENELITIAN}

Penelitian yang berjudul manajemen ekstrakurikuler dalam upaya pengembangan diri santri Pondok Pesantren Al-luqmaniyyah ini menggunakan jenis penelitian kualitatif deskriptif, karena dalam penelitian ini peneliti bermaksud mendeskripsikan dan menganalisi fenomena atau kegiatan dalam obyek tertentu. Metode kualitatif ini dilakukan sebagai prosedur penelitian dalam menghasilkan data deskriptif, yaitu data yang dihasilkan berupa kata-kata tertulis ataupun lisan dari objek yang diteliti. ${ }^{8}$ Adapun yang dimaksud dengan penelitian kualitatif adalah penelitian yang mendapatkan data dengan menggunakan latar alamiah dengan tujuan untuk menafsirkan fenomena yang terjadi dengan melibatkan berbagai metode yang ada. ${ }^{9}$ Hal ini menuntut peneliti sebagai insturmen inti dalam dalam mendapatkan data. Sumber data penelitian adalah tempat, orang atau responden sebagai sarana memperoleh informasi. Pemilihan informan dalam penelitian ini menggunakan teknik Purposive sampling (sampel bertujuan). Purposive adalah mereka yang menurut peneliti memiliki informasi yang

${ }^{8}$ Anis Fuad, Kadung Sapto Nugroho, Panduan Praktis Penelitian Kualitatif, (Yogyakarta:Graha Ilmu, 2014), hlm. 54.

${ }^{9}$ Lexy J. moleong, Metode Penelitian Kualitatif, (bandung: Rosda Karya, 2007), hlm.5. 
dibutuhkan dalam penelitian ini, dikarenakan dalam kesehariannya mereka selalu berusan dengan permasalah yang sedang diteliti. ${ }^{10}$

Teknik pengumpulan data yang digunakan peneliti dalam penelitian ini, yaitu metode observasi, wawancara, dan dokumentasi. Observasi dalam penelitian kualitatif adalah berbetuk narasi atau deskripsi dari hal-hal yang dilakukan subyek dalam kondisi alami (natural settings). Observasi yang peneliti laksanakan menggunakan observasi partisipatif yakni peneliti mengamati apa yang dikerjakan orang, mendengarkan apa yang mereka ucapkan dan berpartisipasi dalam aktivitas mereka dalam arti peneliti terlibat langsung dalam kegiatan sehari-hari orang yang sedang diamati. Wawancara mendalam (In-depth Interview) menjadi teknik yang peniliti gunakan karena dalam teknik ini peneliti bisa tanya jawab sambil bertatap muka dengan responden dan bisa terlibat langsung dalam kehidupan sosial dari responden dengan waktu yang relatif lama. Metode Dokumentasi adalah proses pengumpulan catatan harian, dokumen, dan administrasi yang relevan dengan masalah yang diteliti, sehingga diperoleh data sebagai penunjang penelitian. ${ }^{11}$

\section{HASIL DAN PEMBAHASAN}

\section{Konsep Manajemen Ekstrakurikuler Pondok Pesantren Al- Luqmaniyyah}

Tipologi pondok pesantren di Indonesia terbagi ke dalam tiga kategori, yaitu pesantren Salafiyah, pesantren Khalafiyah, dan pesantren Campuran/kombinasi. ${ }^{12}$ Apabila dilihat dari tipologi pondok pesantren tersebut Al-Luqmaniyyah merupakan salah satu pondok pesantren yang bertipologi pesantren Salafiyyah, dimana dalam menyelenggarakan pembelajarannya masih menggunakan sistem tradisional yaitu dengan metode sorogan dan bandongan serta berkonsentrasi pada kitab-kitab klasik. hlm. 218.

${ }^{10}$ Sugiyono, Metode Penelitian Administrasi,(Bandung : Alfabeta, 2008),

11 Suharsimi, arikunto, Prosedur Penelitian Suatu Pendekatan Praktik, (Jakarta: Rineka Cipta, 2013hlm. 206.

12 Departemen Agama RI, Pondok pesantren dan Madrasah Diniyah Pertumbuhan dan Perkembanagnnya, (Jakarta: Direktoral Jendral Kelembagaan Islam, 2003), hal.29. 
pesantren Al-Luqmaniyyah juga memiliki kegiatan ekstrakurikuler yang merupakan kegiatan tambahan di luar jam pelajaran dalam rangka mengembangkan potensi dan minat bakat yang dimiliki santri. Kemunculan ekstrakurikuler terjadi pada tahun 2006 dan terus berkembang sampai saat ini. Pada tahun 2014 keseriusan Pondok Pesantren Al-luqmaniyyah dalam mengurus ekstrakurikuler dibuktikan dengan berdirinya Departemen bidang Pengembangan Sumber Daya Santri (PSDS).

Tujuan lain dari keberadaan ekstrakurikuler di Pondok Pesantren AlLuqmaniyyah adalah agar santri bisa beraktivitas di dalam pondok. Dengan mayoritas santri adalah mahasiswa yang tentunya memiliki kegiatan yang begitu padat, tentunya menguras fikiran dan ingin mencari suasana serta kegiatan baru di luar pondok. Dengan adanya ekstrakurikuler bisa meminimalir santri melakukan kegiatan di luar pondok yang sebenarnya di dalam pondok juga ada. Jika melihat konsep adanya ekstrakurikuler yang dikembangkan oleh Pondok Pesantren Al-Luqmaniyyah sangat sesuai dengan salah satu tujuan umum berdirinya Pondok Pesantren yaitu untuk menyiapkan santri sebagai kader bangsa yang tangguh, memiliki keimanan dan ketaqwaan kepada Allah SWT, berakhlak mulia, terampil, dan beramal shaleh. Karena dengan santri yang memiliki kreatifitas tinggi serta memiliki keterampilan yang lebih bisa memudahkan mereka dalam menghadapi kehidupan di masyarakat kelak. Dan semua itu bisa tercapai salah satunya dengan adanya ekstrakurikuler di pondok pesantren. Dari pemaparan di atas dapat disimpulkan bahwa konsep kehadiran ekstrakurikuler adalah sebagai berikut:

Pertama, dibentuknya Bidang Pengembangan Sumber Daya Santri sebagai departemen untuk mengelola ekstrakurikuler di Pondok Pesantren Al-Luqmaniyyah, sehingga proses penyaluran minat dan bakat santri bisa terprogram dengan baik.

Kedua, dalam proses terbentuknya ekstrakurikuler di Pondok Pesantren Al-Luqmaniyyah berawal dari beberapa santri yang berkumpul membentuk sebuah komunitas kemudian setelah eksistensi komunitas 
tersebut terlihat maka pengurus Bidang Pengembangan Sumber Daya Santri mengukuhkannya sebagai sebuah ekstrakurikuler.

Ketiga, ekstrakurikuler yang dicetuskan pesantren Al-Luqmaniyyah bertujuan agar santri lebih banyak beraktivitas di lingkungan pesantren. Sehingga santri tidak mencari kegiatan-kegiatan yang berada di luar lingkungan pesantren yang bisa menyebabkan melanggar aturan pondok. Seperti meninggalkan mengaji dan tidak mujahadah.

Keempat, dalam proses kegiatannya, ekstrakurikuler tidak boleh menggangu kegiatan mengaji. Karena pada dasarnya, ekstrakurikuler adalah kegiatan tambahan yang mendukung kegiatan utama di Pondok Pesantren Al-Luqmaniyyah.

\section{Penerapan Manajemen Ekstrakurikuler di Pondok Pesantren Al- Luqmaniyyah}

Kegiatan ekstrakurikuler adalah kegiatan yang di lakukan dalam rangka pengembangan minat dan bakat di luar jam pelajaran. Kehadiran manajemen dapat mengelola sumber daya yang kita miliki, baik sumber daya manusia, materi, uang, metode dan yang lainnya untuk mencapai tujuan yang ditentukan secara efektif dan efisien. ${ }^{13}$ Manajemen ekstrakurikuler di Pondok Pesantren Al-Luqmaniyyah dapat dianalisa menggunakan berbagai pendekatan, namun peneliti melakukan analisa menggunakan teori George R. Terry yang menyebutkan bahwa Fungsi manajemen terdapat empat bagian yaitu, perencanaan, pengorganisasian, pelaksanaan, dan pengawasan. 14

\section{Perencanaan}

Perencanaan merupakan tindakan menetapakan terlebih dahulu apa yang diinginkan di masa yang akan datang. Dengan adanya rencana yang jelas, sehingga bisa memudahkan dalam proses pelaksanaannya. Ada tiga hal yang selalu berhubungan dalam proses pembuatan perencaan yaitu, perumusan tujuan yang ingin dicapai, pemilihan program untuk mencapai tujuan, dan pengerahan sumber daya.

13 Husaini Usman, Manajemen, teori Praktik dan Riset Pendidikan, (Jakarta: Bumi Aksara, 2006) hal. 2

${ }^{14}$ Nanang Fattah, Landasan Manajemen Pendidikan, (Bandung: Remaja Rosdakarya, 1996,) hal. 13. 
Perumusan Tujuan Ekstakurikuler,

Sebagaimana di paparkan sebelumnya dalam konsep ekstrakurikuler di Pondok Pesantren Al-luqmaniyyah, dari hasil wawancara penulis dengan narasumber, menyatakan bahwa rumusan tujuan ekstrakurikuler di $\mathrm{Al}$ Luqmaniyyah yaitu : Kehadiran ekstrakurikuler bertujuan sebagai sarana pengembangan minat dan bakat santri. Manusia diciptakan berbeda-beda dengan bakat yang berbeda-beda pula. Di Pondok pesantren AlLuqmaniyyah santri diperbolehkan berkreasi sesuka hati sesuai keinginan dan hobi mereka. ${ }^{15}$ Kehadiran ekstrakurikuler bertujuan agar para santri lebih banyak beraktivitas di dalam pondok. Sehingga kegiatan apapun yang ekstrakurikuler lakukan selama membuat para santri nyaman dan betah tinggal di dalam pondok itu yang akan pengurus pondok dukung dan meninggalkan kegiatan tambahan yang biasa mereka lakukan di luar pondok sebagai penyaluran minat dan bakatnya. ${ }^{16}$

Pemilihan Program untuk Mencapai Tujuan

Ekstrakurikuler yang ada di Pondok Pesanten Al Luqmaniyyah terdapat 11 jenis terbagi ke dalam 13 nama ekstrakurikuler. ${ }^{17}$ Pemilihan program ekstrakurikuler tersebut seluruhnya merupakan kegiatan yang diinginkan oleh santri dan dibuat oleh santri, pengurus pondok hanya mengukuhkan ekstra-ekstra yang diusulkan oleh santri dengan berbagai pertimbangan. Ekstrakulikuler tersebut adalah: ${ }^{18}$ Seni hadroh, LQ FC (Luqmaniyyah Football Club), LBC (LQ Beauty Club), English Club,

15 Hasil wawancara dengan Maskur Hamba, wakil ketua pusat bidang Pengembangan Sumber Daya Santri Pondok Pesantren Al-Luqmaniyyah pada Jumat, 15 juli 2017 di serambi masjid Pondok Al-Luqmaniyyah, pukul 00.05-00.30 WIB.

16 Kumpulan hasil wawancara dengan Romdhon M. Adi dan Masykur Hamba selaku ketua dan wakil ketua pusat bidang Pengembanagn Sumber Daya Santri Pondok Al-Luqmaniyyah pada tanggal 11-17 Juni 2017.

${ }^{17}$ Data dokumentasi soft file program kerja ketua ekstrakurikuler tahun 2016 kepada bidang Pengembangan Sumber Daya Santri pesantren AlLUqmaniyyah, diambil pada tanggal 30 Agustus 2017.

${ }^{18}$ Kumpulan hasil wawancara dengan M. Raka anantama dan Afifah Ikram selaku ketua PSDS komplek putra dan putri Pesantren Al-Luqmaniyyah pada kamis, 15 Juni 2017 sampai 29 juli 2017. 
Qolamuna ( Seni Kaligrafi), LQ Handy Craf (seni kerajinan tangan), Buletin, JQH (Jami'ah Quro' Wal Hufadz), Tilawah, LBM (Lajnah Bahtsul Masail), Arabic Club.

Dalam rangka mencapai tujuan yang diinginkan terutama agar minat dan bakat santri bisa terasah dan tentunya para santri tidak mencari kegiatan di luar pondok, dalam hal ini bidang Pengembangan Sumber Daya Santri menetapkan beberapa program diantaranya: ${ }^{19}$ Kegiatan Rutinan Mingguan, Dalam setiap minggunya PSDS memberi waktu dan tempat kepada setiap ekstrakurikuler untuk bisa menggelar latihan rutin mingguan. Kegiatan Bulanan, Setiap ekstrakurikuler bisa mengikuti event yang di selenggarakan oleh pihak luar baik itu swasta atau pemerintah. Dalam kaitannya dengan kegiatan bulanan ini tentunya tidak ada kepastian, karena belum tentu ada suatu perlombaan ataupun acara yang diselenggarakan. Kegiatan Tahunan, Pondok Pesantren Al-Luqmaniyyah memberi kebebasan bagi para santrinya untuk berkreasi sesuai minat dan bakat mereka masingmasing. Dalam hal ini PSDS membuat suatu rangkaian kegiatan yang diselenggarakan setiap tahunnya. Diantara program tahunan ekstrakurikuler di Pondok Pesantren Al-Luqmaniyyah adalah: Bulan Ekspresi Ekstra (BEE) merupakan bulan yang ditunggu-tunggu penggiat ekstra di Al-Luqmaniyyah. Dalam ajang ini, setiap ekstra diharuskan menyelenggarakan event ekstranya masing-masing. Kegiatan ini menjadi rutinan tahunan pada bulan Februari. ${ }^{20}$ Festival Hadroh antar Pondok Pesantren Se-DIY, Keberadaan hadroh di Pondok Pesantren Al-Luqmaniyyah merupakan elemen yang tidak bisa di pisahkan dari ciri khas pesantren. Ekstrakurikuler hadroh di AlLuqmaniyyah ada tim Hadroh Ababil untuk santri putra dan Hadroh Azkiya untuk santri putri. Untuk kegiatan festival Hadroh antar Pondok Pesantren Se-DIY menjadi program khusus dari PSDS. Melihat geliat perkembangan

${ }^{19}$ Kumpulan hasil wawancara dengan M. Raka anantama dan Afifah Ikram selaku ketua PSDS komplek putra dan putri Pesantren Al-Luqmaniyyah pada kamis, 15 Juni 2017 sampai 29 juli 2017.

${ }^{20}$ Kumpulan hasil wawancara dengan M. Raka anantama dan Afifah Ikram selaku ketua PSDS komplek putra dan putri Pesantren Al-Luqmaniyyah pada kamis, 15 Juni 2017 sampai 29 juli 2017. 
hadroh di daerah Yogyakarta yang semakin ramai, maka PSDS mengambil bagian dengan adanya festival hadroh antar pondok Pesantren Se-DIY bisa mempererat silaturahmi antar pondok serta sebagai ajang promosi dari Pondok Pesantren Al-Luqmaniyyah itu sendiri. ${ }^{21}$ Turnamen Futsal Antar Santri, Kegiatan ini sebagai bagian acara dalam memperingati hari lahir Pondok Pesantren Al-Luqmaniyyah. Dalam prosesnya, kegiatan ini diikuti oleh beberapa pondok pesantren yang ada di lingkup provinsi Yogyakarta. Menentukan Sumber Daya yang Diinginkan

Pada tahun penerimaan santri baru, Pondok Pesantren AlLuqmaniyyah mengadakan kegiatan Masa Orientasi Santri Baru (MOSBA) sebagai wahana bagi santri dalam mengenal lebih jauh tentang AlLuqmaniyyah, dalam event ini PSDS juga melakukan perannya untuk mempromosikan ekstra-ekstra yang ada di Al-Luqmaniyyah, juga sekaligus perekrutan anggota baru. ${ }^{22}$ Pelaksanaan kegiatan ekstrakurikuler di Pondok Pesantren Al-Luqmaniyyah tidak hanya terfokus di area pondok pesantren saja, dikarenakan fasilitas yang masih kurang lengkap, sehingga sebagian kegiatan ekstra menggunakan fasiltas yang ada di luar pondok. ${ }^{23}$ Bidang Pengembangan Sumber Daya Santri menetukan waktu pelaksanaan kegiatan ekstrakurikuler agar tidak menggangu kegiatan pokok yang ada di Pondok. Pemilihan waktu mayoritas disepakati adalah hari sabtu dan minggu. Pemilihan waktu tersebut dikarenakan mayoritas santri adalah mahasiswa maka pada hari-hari tersebut biasanya santri tidak memiliki jadwal perkuliahan di kampusnya masing-masing dan juga pada hari tersebut biasanya santri mencari kegiatan lain di luar pondok pesantren. Berikut

${ }^{21}$ Hasil wawancara dengan M. Raka anantama ketua PSDS komplek putra Pesantren Al-Luqmaniyyah pada kamis, 15 Juni 2017 di Kantor komplek putra pada pukul 19.39-20.03 WIB.

${ }^{22}$ Hasil wawancara dengan M. Raka anantama ketua PSDS komplek putra Pesantren Al-Luqmaniyyah pada kamis, 15 Juni 2017 di Kantor komplek putra pada pukul 19.39-20.03 WIB.

${ }^{23}$ Kumpulan hasil wawancara dengan M. Raka anantama dan Afifah Ikram selaku ketua PSDS komplek putra dan putri Pesantren Al-Luqmaniyyah pada kamis, 15 Juni 2017 sampai 29 juli 2017. 
jadwal waktu dan tempat pelaksanaan kegiatan ekstra yang ada di Pondok Pesantren Al-Luqmaniyyah

Dana merupakan salah satu aspek yang sangat penting berjalannya suatu ekstra. Pondok Pesantren Al-Luqmaniyyah mengelontorkan dana agar ekstrakurikuler yang ada dapat melaksanakan kegiatannya. Setiap ekstra mendapatkan pendanaan yang berbeda-beda satu sama lainnya, tergantung kebutuhan dan keperluan mereka dalam melaksanakan kegiatan. Anggaran ekstrakurikuler tersebut diambil dari APBP (Anggaran Pendapatan dan Belanja Pesantren) yang telah ditetapakan pada rapat anggaran dana. Berikut adalah anggaran dana ekstrakurikuler di Al-Luqmaniyyah:

Anggaran dana ekstrakurikuler Pondok Pesantren Al-Luqmaniyyah tahun $2017^{24}$

\begin{tabular}{|c|c|c|}
\hline No & Ekstra & Anggaran perbulan \\
\hline 1 & Hadroh ababil & Rp 70.000 \\
\hline 2 & LQFC & Rp 70.000 \\
\hline 3 & Qolamuna & Rp 100.000 \\
\hline 4 & English Club & $\begin{array}{ll}\mathrm{Rp} & 70.000\end{array}$ \\
\hline 5 & Lajnah Bahtsul Masail & Rp 70.000 \\
\hline 6 & Buletin Iqra & Rp 170.000 \\
\hline 7 & Hadroh Azkiya & Rp $\quad 30.000$ \\
\hline 8 & LQ Handy Craff & $\begin{array}{ll}\mathrm{Rp} & 90.000\end{array}$ \\
\hline 9 & LQ Beauty Club & Rp $\quad 30.000$ \\
\hline 10 & Buletin An-Najwa & Rp 170.000 \\
\hline 11 & Jami'ah Quro Wal Hufadz & Rp. 150.000 \\
\hline 12 & Tilawah & Rp 170.000 \\
\hline 13 & Arabic Club & $\begin{array}{ll}\mathrm{Rp} & 30.000\end{array}$ \\
\hline
\end{tabular}

Berdasarkan pemaparan di atas terkait perencanaan kegiatan ekstrakurikuler di Pondok Pesantren Al-Luqmaniyyah yang di dalamnya memuat perumusan tujuan ekstrakurikuler, pemilihan jenis program

24 Hasil wawancara dengan Afifah Ikram, koordinator bidang Pengembangan Sumber Daya Santri komplek putri Pondok Pesantren AlLuqmaniyyah pada sabtu, 29 Juli 2017 tempat kantor pusat Al-Luqmaniyyah pukul 10.55-11.34 WIB. 
ekstrakurikuler dan penentuan sumber daya yang akan digunakan dalam kegiatan ekstrakurikuler. Sementara literatur yang peneliti baca bahwa perencanaan harus memuat minimal tiga tahapan yaitu perumusan tujuan yang ingin dicapai, pemilihan program untuk mencapai tujuan dan pengerahan sumber daya, maka menurut peneliti perencanaan yang yang dibuat oleh Pengembangan Sumber Daya Santri di Pondok Pesantren AlLuqmaniyyah sesuai dengan literature dikarenakan memuat tiga tahap perencanaan tersebut.

\section{Pengorganisasian}

Pengorganisasian ekstrakurikuler di Pondok Pesantren AlLuqmaniyyah cukup tertata rapi, hal terlihat dari struktur kepengurusan serta pemberian tugas terhadap bidang Pengembangan Sumber Daya Santri dalam membina ekstra-ekstra yang ada untuk mencapai tujuan yang ditetapkan. Berikut ini adalah struktur organisasi bidang Pengembangan Sumber Daya Santri Pondok Pesantren Al-Luqmaniyyah:

Susunan Organisasi bidang Pengembangan Sumber Daya Santri Pondok Pesantren Al-Luqmaniyyah terdiri dari Ketua pusat pengembangan sumber daya santri, wakil ketua pusat pengembangan sumber daya santri, pengembangan sumber daya santri komplek putra, pengembangan sumber daya santri komplek putri, dan ekstrakurikuler.

Berdasarkan tabel di atas dapat dijelaskan bahwa tugas kepala dan wakil kepala pusat bidang PSDS Pondok Pesantren Al-luqmaniyyah yaitu Menggali dan mengembangkan kreatifitas santri, Bertanggung jawab terhadap hidup dan matinya kegiatan ekstra pondok Sedangkan pada PSDS ditingkat komplek proses pembagian tugas semakin rinci, Setiap anggota PSDS ditugaskan untuk membimbing dan mendampingi ekstra yang telah ditentukan

\section{Pelaksanaan}

Dalam proses pelaksanaan ekstrakurikuler di Pondok Pesantren AlLuqmaniyyah peran Pengembangan Sumber Daya Santri komplek sangat penting dalam menggerakan seluruh ekstrakurikuler untuk bekerja dengan 
sendiri dan penuh kesadaran dalam mencapai tujuan yang diinginkan. Dalam proses melaksanakan tugasnya yang telah di tetapkan pada tahap perencanaan, PSDS komplek melaksanakan tugasnya melalui beberapa kegiatan:

Pelaksanaan Kegitan Mingguan

Kegiatan rutinan mingguan merupakan kegiatan yang harus dilaksanaan oleh ekstra-ekstra yang ada di Pesantren Al-Luqmaniyyah, setiap ekstra di dampingi oleh anggota PSDS. Selain itu dalam proses pelaksanaannya anggota PSDS memberi motivasi dan semangat kepada setiap ketua ekstrakurikuler agar bisa istiqomah dalam menjalankan program-program yang mereka susun. Berikut ini adalah salah satu gambar dari kegiatan rutinan mingguan ekstrakurikuler di Pondok Pesantren AlLuqmaniyyah.

Pelaksanaan Kegiatan Bulanan

Kegiatan bulanan merupakan kegiatan kondisional dari setiap ekstra yang ada di Pondok Pesantren Al-Luqmaniyyah, karena kegiatan ini menunggu adanya event yang di selenggarakan oleh pihak luar dan hal ini belum pasti ada setiap bulannya. Dalam pelaksanaannya PSDS ditugaskan mendampingi dan memenuhi seluruh kebutuhan anggota ekstra yang sedang mengikuti suatu perlombaan. ${ }^{25}$

Pelaksanaan Kegiatan Tahunan

Kegiatan tahunan yang diselenggarakan oleh Bidang PSDS pesantren Al-Luqmaniyyah terdiri dari Bulan Ekspresi Ekstra, Festival Hadroh Antar Pondok Pesantren se-DIY, dan Turnamen Futsal Santri Antar Pondok Pesantren Se-DIY. Peran PSDS dalam pelaksanaan event-event tersebut yaitu membantu panitia pelaksana kegiatan.

Dari data yang diperoleh di atas apabila kita membandingkan dengan teori yang dikemukan oleh George $\mathrm{R}$ Terry bahwa pelaksanaan

${ }^{25}$ Hasil wawancara dengan M. Raka anantama ketua PSDS komplek putra Pesantren Al-Luqmaniyyah pada kamis, 15 Juni 2017 di Kantor komplek putra pada pukul 19.39-20.03 WIB. 
merupakan usaha untuk menggerakan anggota-anggota kelompok sedemikian rupa sehingga mereka berkeinginan dan berusaha untuk mencapai sasaran perusahaan dan sasaran anggota perusahaan tersebut. ${ }^{26}$ Sedangkan dalam proses pelaksanaan ekstrakurikuler yang ada di Pondok Pesantren Al-Luqmaniyyah peran bidang Pengembangan Sumber Daya Santri sangat penting dalam memberikan motivasi, dan menggerakan ketua ekstrakurikuler disetiap kegiatannya, baik kegiatan mingguan, bulanan dan tahunan. Sehingga roda kegiatan setiap ekstra dapat berjalan baik.

\section{Pengawasan}

Untuk menjamin keterlaksanaan program ekstrakurikuler, bidang Pengembangan Sumber Daya Santri Pondok Pesantren Al-Luqmaniyyah melakukan pengawasan. Yaitu, Pengawasan langsung dilakukan pada saat program ekstrakurikuler berlangsung, anggota PSDS yang bertugas mendampingi kegiatan ekstra setiap minggunya, juga bertugas mengawasi keberlangsungan program ekstra tersebut. ${ }^{27}$ Pengawasan tidak langsung adalah pengawasan jarak jauh. Pengawasan ini dilakukan melalui hasil laporan dari anggota baik laporan lisan, tulisan dan laporan khusus. ${ }^{28}$ PSDS melakukan kumpulan setiap bulannya bersama seluruh ketua ekstrakurikuler yang ada di Pondok Pesantren Al-Luqmaniyyah. Dengan adanya kegiatan ini akan diperoleh data-data berupa keluhan dan keadaan ekstranya dari setiap ketua ekstra baik aspek kemajuan maupun hambatan yang dilalui oleh ekstrakurikuler setiap bulannya, sehingga dijadikan bahan evaluasi untuk pengambilan keputusan dimasa yang akan datang.

Apabila melihat hasil data yang diperoleh dari lapangan bahwa pengawasan yang dilakukan oleh bidang Pengembangan Sumber Daya

${ }^{26}$ Nanang Fattah, Landasan Manajemen Pendidikan, (Bandung: Remaja Rosdakarya, 1996), hal. 72.

27 Hasil wawancara dengan Afifah Ikram, koordinator bidang Pengembangan Sumber Daya Santri komplek putri Pondok Pesantren AlLuqmaniyyah pada sabtu, 29 Juli 2017 tempat kantor pusat Al-Luqmaniyyah pukul 10.55-11.34.

${ }^{28}$ Usman Efendi, Asas Manajemen, (Jakarta: Rajawali Pers, 2014), Hal. 208. 
Santri Pesantren Al-Luqmaniyyah menggunkan dua cara yaitu pengawasan langsung dengan melibatkakan anggota PSDS sebagai pengawas dalam kegiatan rutinan ekstra, dan pengawasan tidak langsung dilakukan dengan pertemuan satu bulan sekali dengan seluruh elemen ekstrakurikuler.

\section{Pengembangan Diri Santri Pondok Pesantren Al-Luqmaniyyah}

Pengembangan diri adalah proses pembentukan sikap dan prilaku yang relatif menetap melalui pengalaman yang berulang-ulang sampai pada tahap otonomi (kemandirian) mengenai suatu prilaku tertentu. Selain itu, pengembangan diri bertujuan untuk menunjang pendidikan peserta didik dalam mengembangkan minat, bakat, kreativitas, kompetensi dan kebiasaan dalam kehidupan keagamaan, kemampuan sosial, kemampuan belajar, wawasan dan perencanaan karir, kemampuan pemecahan masalah dan kemandirian. ${ }^{29}$ Sehingga pengalaman dan pengetahuan yang berulang-ulang akan membawa santri pada tahap kemandirian, baik kemandirian emosi, ekonomi, intelektual, sosial. ${ }^{30}$ Proses pengembangan diri di Pondok Pesantren Al-Luqmaniyyah menghasilkan beberapa hal dalam diri santri. Semua dampak pengembangan diri itu meliputi kemandirian yang di dalamnya memuat kemandirian emosi, ekonomi, intelektual, sosial maupun tujuan pengembangan diri sebagai penunjang pendidikan peserta didik secara tersirat bisa terlihat melalui hasil yang peroleh ekstrakurikuler berupa output maupun outcome.

Output dari pengembangan diri santri adalah hasil langsung dan segera dari kegiatan ekstrakurikuler yang dilakukan oleh Pesantren AlLuqmaniyyah. Output ini bisa dilihat dari input santri yang awalnya tidak mempunyai keahlian tetapi setelah masuk dan mengikuti kegiatan ekstrakurikuler mereka akhirnya memiliki kemampuan yang berguna bagi diri sendiri dan menjadi bekal kelak di kehidupan masyarakat, salah satu output adalah prestasi yang diraih beberapa bidang ekstrakurikuler. Berikut

${ }^{29}$ Departemen Agama, Pedoman Kegiatan Pengembangan Diri, (Jakarta : 2005), Hal. 5

30 Desmita, Psikologi Perkembangan Peserta Didik, (Bandung: Rosdakarya, 2009), hal. 186. 
adalah output berupa prestasi santri yang dihasilkan oleh beberapa ekstrakurikuler Pondok Pesantren Al-Luqmaniyyah :

Perolehan prestasi ekstrakurikuler

Pesantren Al-Luqmaniyyah tahun $2017^{31}$

\begin{tabular}{|c|c|c|c|}
\hline Nama ekstra & Tahun & Jenis kegiatan & Prestasi \\
\hline \multirow[t]{2}{*}{ Hadroh Ababil } & 2016 & $\begin{array}{l}\text { Festival seni \& Hadroh } \\
\text { Majlis Pemuda Islam } \\
\text { Indonesia Bantul }\end{array}$ & Juara I \\
\hline & 2016 & $\begin{array}{l}\text { Festival Hadroh Se- } \\
\text { DIY \& Jawa Tengah }\end{array}$ & Juara II \\
\hline \multirow[t]{2}{*}{ LQFC } & 2016 & $\begin{array}{l}\text { Turnamen Futsal Antar } \\
\text { Santri Se-DIY }\end{array}$ & Semifinal dan Top Skor \\
\hline & 2017 & Nurma Cup & $\begin{array}{l}\text { Semifinal dan Suporter } \\
\text { terbaik }\end{array}$ \\
\hline $\begin{array}{l}\text { Buletin } \\
\text { Annajwa }\end{array}$ & 2017 & $\begin{array}{l}\text { Write For Feace } \\
\text { bersama Lutfi JW }\end{array}$ & $\begin{array}{l}\text { Penyelenggara dan } \\
\text { peserta }\end{array}$ \\
\hline \multirow[t]{3}{*}{ LQ Handy Craf } & 2017 & $\begin{array}{l}\text { Pelatihan pemanfaatan } \\
\text { barang bekas di Posko } \\
\text { KKN }\end{array}$ & Pemateri \\
\hline & 2017 & $\begin{array}{l}\text { Pelatihan pemanfaatan } \\
\text { barang bekas di Posko } \\
\text { KKN }\end{array}$ & Pemateri \\
\hline & 2017 & $\begin{array}{l}\text { Tamu Undangan di } \\
\text { Suka TV dalam acara } \\
\text { Inovasi Muda }\end{array}$ & Pemateri \\
\hline \multirow{2}{*}{$\begin{array}{l}\text { Hadroh } \\
\text { Azkiyya }\end{array}$} & 2016 & $\begin{array}{l}\text { Festival Seni Hadroh } \\
\text { Al-Ukhuwah } \\
\text { Maguwoharjo } 2016\end{array}$ & Juara Kostum Terbaik \\
\hline & 2017 & $\begin{array}{lr}\text { Festival Hadroh dalam } \\
\text { Rangka } & \text { Harlah } \\
\text { Universitas } & \text { Islam } \\
\text { Indonesia } & \\
\end{array}$ & Peserta \\
\hline Buletin Iqra & 2017 & $\begin{array}{lr}\text { Lomba Cerpen } & \text { Santri } \\
\text { Nasional } & 2017 \\
\text { CSSMORA UIN Sunan } \\
\text { Kalijaga }\end{array}$ & $\begin{array}{l}\text { kategori } 20 \text { Naskah } \\
\text { Terbaik }\end{array}$ \\
\hline
\end{tabular}

Dari tabel di atas dapat kita pahami bahwa prestasi ekstrakurikuler di tahun 2016-2017 cukup baik untuk sekelas pondok pesantren Salaf, meskipun prestasi yang didapat tidak merata diperoleh oleh seluruh ekstrakurikuler yang ada di pesantren Al-Luqmaniyyah. Karena memang tujuan dan fungsi awal dari keberadaan ekstrakurikuler di Pesantren AlLuqmaniyyah adalah sebagai alat penyalur minat dan bakat santri. Sedangkan outcome ekstrakurikuler Pondok Pesantren Al-Luqmaniyyah adalah hasil efek jangka panjang berupa dampak, manfaat dari proses

31 Dokumentasi data prestasi ekstrakurikuler bidang Pengembangan Sumber Daya santri tahun 2016-2017. 
kegiatan ekstrakurikuler. Berdasarkan hasil penelusuran peneliti ada beberapa outcome yang dihasilkan dari ekstrakurikuler antara lain ekstrakurikuler hadroh putra Ababil, ekstra ini kerap menjadi bintang tamu dalam suatu kegiatan misalnya acara khitanan, aqiqah dan nikahan. ${ }^{32}$ Sehingga ekstra ini bisa menghasilkan keuntungan dari hasil pentas tersebut.

Ada juga LQ Handy Craft, ekstra ini mampu mendatangkan keuntungan dari produk yang mereka hasilkan melalui pemanfaatan barang bekas, selain itu kerap kali ekstra LQ Handy Craf menjadi pemateri dalam sebuah pelatihan sehingga mendapatkan upah dari jasa tersebut. Melalui lulusannya sebuah program bisa dilihat seberapa jauh dampak dan manfaatnya hasil dari kegiatan program tersebut. Hasil dari ekstrakurikuler di Pondok Pesantren Al-Luqmaniyyah adalah menciptakan lulusan ekstra yang mampu bersaing di dunia kerja dan bermanfaat di masyarakat. Diantara alumninya adalah ada yang bergerak dibidang jasa pembuatan souvenir pernikahan, box bunga, kado wisuda, dan lain-lain. Wirausaha ini bernama Twiny Craft, dirintis oleh dua orang santri kembar, mereka adalah alumni ekstrakurikuler LQ Handy Caft. Karya tangan ini dijual dari kisaran harga Rp 15.000- 200.000..$^{33}$ Mereka adalah lulusan dari ekstra Qolamuna Pondok Pesantren Al-Luqmaniyyah. Dalam sekali pekerjaan mereka mendapatkan imbalan sekitar satu juta. ${ }^{34}$

\section{KESIMPULAN}

Berdasarkan analisis data pelaksanaan ekstrakurikuler dalam upaya pengembangan diri santri di Pondok Pesantren Al-Luqmaniyyah Yogyakarta, maka peneliti menarik simpulan bahwa Konsep ekstrakurikuler yang dikembangkan oleh Pondok Pesantren Al-Luqmaniyyah adalah sebagai

32 Hasil wawancara dengan M. Raka anantama selaku ketua PSDS komplek putra Pesantren Al-Luqmaniyyah pada kamis, 15 Juni 2017 di Kantor komplek putra pada pukul 19.39-20.03 WIB.

${ }^{33}$ Hasil wawancara dengan Neneng Suryani putri alumni ekstra LQ Handy Craft pada tanggal 18 Oktober 2017, pukul 09.00 WIB.

34 Hasil wawancara dengan Dimas Mahaputra alumni ekstra Qolamuna pada tanggal 18 Oktober 2017 pukul 10.00 WIB. 
wadah pengembangan diri bagi santri, sehingga santri bisa mengembangkat minat dan bakat yang dimilikinya. Lahirnya bidang Pengembangan Sumber Daya Santri (PSDS) menjadi vital dalam tugas mengatur seluruh ekstrakurikuler di pesantren Al-Luqmaniyyah. Penerapan manajemen ekstrakurikuler di Pondok Pesantren Al-Luqmaniyyah Yogyakarta telah sesuai dengan fungsi-fungsi manajemen yang ada meliputi pertama perencanaan, dilakukan melalui proses perumusan tujuan ekstrakurikuler, Pemilihan program ekstra, dan penentuan sumber daya yang akan digunakan. Kedua pengorganisasian, dengan memberikan tugas kepada bidang Pengembangan Sumber Daya Santri untuk mengelola ekstra. Ketiga pelaksanaan, kegiatan ekstrakurikuler yang telah ditetapkan dengan jadwal kegiatan rutinan mingguan, bulanan dan tahunan. Keempat pengawasan, dimana dalam setiap kegiatan ekstrakurikuler PSDS akan menilai bahwa pelaksanaan benar-benar sesuai dengan perencanan, dan mengkoreksi penyimpangan untuk perbaikan dimasa yang akan datang. Yang keempat fungsi tersebut telah di maksimalkan oleh bidang Pengembangan Sumber Daya Santri. Hasil dari kegiatan ekstrakurikuler di Pondok Pesantren AlLuqmaniyyah dapat dilihat dari jumlah yang mengikuti ekstrakurikuler setiap tahunnya yang terus bertambah. Sedangkan hasil dari pengembangan diri dapat dilihat melalui output dan outcome kegiatan ekstrakurikuler. Output ekstrakurikuker mengasilkan santri memiliki skill lebih setelah mengikuti ekstra, sedangkan outcome bisa dilihat dari beberapa lulusannya yang bisa berwirausaha dengan skill yang didapatnya dari kegiatan ekstra, seperti ada lulusan yang menjadi guru ekstra hadroh disekolah formal, membuat kerajinan tangan, jasa pembuatan kaligrafi masjid.

\section{REFERENSI}

Agama, Departemen Pedoman Kegiatan Pengembangan Diri, Jakarta : 2005. arikunto, Suharsimi, Prosedur Penelitian Suatu Pendekatan Praktik, Jakarta: Rineka Cipta, 2013.

Dawam, Ainurrofiq dan Ahmad Ta'arifin, Manajemen Madrasah Berbasis Pesantren, Yogyakarta: ListafariskaPutra, 2005.

Depag Direktorat Jendral Kelembagaan Agama Islam, Panduan Kegiatan Ekstrakurikuler Pendidikan Agama Islam, Jakarta, 2005. 
Desmita, Psikologi Perkembangan Peserta Didik, Bandung: Rosdakarya, 2009.

Dhofier, Zamakhsyri Tradisi Pesantren Studi Tentang Padangan Hidup Kyai, Jakarta : LP3ES, 2013.

Efendi, Nur Manajemen Perubahan di Pesantren, Sleman: Kalimedia, 2016.

Efendi, Usman, Asas Manajemen, Jakarta: Rajawali Pers, 2014

Farehan, Hamdan dan Syarifuddin, Titik Tengkar Pesantren Resolusi Konflik Pesantren, Yogyakarta: Pilar Religia, 2005.

Fattah, Nanang Landasan Manajemen Pendidikan, Bandung: Remaja Rosdakarya, 1996.

Fuad, Anis dan Kadung Sapto Nugroho, Panduan Praktis Penelitian Kualitatif, Yogyakarta:Graha Ilmu, 2014.

Halim, A. Dkk, Manajemen pesantren, Yogyakarta: Lkis, 2005.

Hasbullah, Dasar-dasar Ilmu Pendidikan, Jakarta: Rajawali Pers, 2011.

I, Arifin dan Slamet, Kepemimpinan Kyai dalam Perubahan

Manajemen Pondok Pesantren;Kasus Ponpes Tebu Ireng Jombang, Yogyakarta: Aditya Media, 2010

Moleong, Lexy J, Metode Penelitian Kualitatif, bandung: Rosda Karya, 2007.

Muahaimin, dkk, Pengembangan Model Kurikulum Tingkat Satuan

Pendidikan pada Sekolah dan Madrasah, Jakarta: Raja Grafindo Persada, 2010.

Nasir, M. Ridlwan Mencari Tipologi Format pendidikan Ideal Pondok Pesantren di Tengah Arus Perubahan, Yogyakarta: Pustaka Pelajar, 2010

Nugroho, Anis Fuad, Kadung Sapto, Panduan Praktis Penelitian Kualitatif, Yogyakarta: Graha Ilmu, 2014.

RI, Departemen Agama, Pondok pesantren dan Madrasah Diniyah Pertumbuhan dan Perkembanagnnya, Jakarta: Direktoral Jendral Kelembagaan Islam, 2003.

Sugiyono, Metode Penelitian Administrasi,Bandung : Alfabeta, 2008.

Sulistryorini, Manajemen Pendidikan Islam, Yogyakarta: Teras, 2009.

Usman, Husaini, Manajemen , Teori, Praktik dan Riset Pendidikan, Jakarta: Bumi Aksara, 2006. 


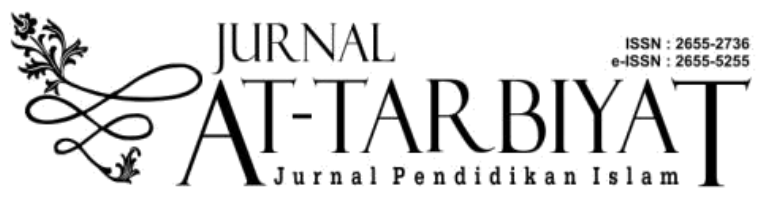

http://jurnal.staiannawawi.com/index.php/At-Tarbiyat

\title{
MANAJEMEN EKSTRAKURIKULER DALAM UPAYA PENGEMBANGAN DIRI SANTRI PONDOK PESANTREN AL-LUQMANIYYAH YOGYAKARTA
}

\author{
Ahmad Hinayatulohi \\ UIN Sunan Kalijaga Yogyakarta
}

\section{Abstrak}

Ekstrakrikuler merupakan wadah yang bisa digunakan untuk proses pengembangan diri santri di pondok pesantren. Pengelolaan yang baik terhadap ekstrakurikuler akan mengembangkan santri sesuai potensi kodratnya. Al-Luqmaniyyah Yogyakarta adalah pondok pesantren salaf yang memiliki manajemen ekstrakurikuler. Lahirnya bidang Pengembangan Sumber Daya Santri menjadi salah satu jawaban dalam mengatur ekstrakurikuler di pesantren Al-Luqmaniyyah. Penelitian ini menggunakan analisis deskriptif-kualitatif dengan Hasil penelitian menyebutkan bahwa konsep lahirnya ekstrakurikuler di pesantren Al-Luqmaniyyah adalah sebagai ajang pengembangan diri santri. Disisi lain tujuan yang ingin dicapai adalah sebagai wadah kegiatan santri di lingkungan pondok pesantren. Sehingga dengan adanya ekstrakurikuler, para santri tidak mencari kegiatan lain di luar lingkungan pesantren. Lahirnya bidang Pengembangan Sumber Daya Santri sebagai manajer dalam mengelola ekstrakurikuler yang ada. Penerapan manajemen ekstrakurikuler melalui empat tahap, yaitu perencanaan, pengorganisasian, pelaksanaan, dan pengawasan. Sedangkan hasil yang dicapai diantaranya, minat santri mengikuti esktrakurikuler bertambah setiap tahunnya, berkurangnya jumlah pelanggaran santri, pengembangan diri yang bertujuan akhir kepada kemandirian santri bisa terlihat melalui kemandirian emosi, intelektual, sosial, dan ekonomi

\section{Abstract}

Extracurricular is a media that can be used for the self-development process of santris in Pesantren (Islamic boarding schools). Good management of extracurricular activities will develop santri according to their natural potential. Al-Luqmaniyyah Yogyakarta is a salaf boarding school that has extracurricular management. The birth of the Santri Resource Development field is one of the answers in arranging 
extracurricular activities in Al-Luqmaniyyah Islamic boarding schools. This study uses descriptive-qualitative analysis with the results of the study stating that the concept of extracurricular birth in Al-Luqmaniyyah is a place for self-development of students. On the other hand the goal to be achieved is as a place for santri activities in Islamic boarding schools. So that with extracurricular activities, the santri did not look for other activities outside the pesantren environment. The birth of the Santri Resource Development field is as a manager in managing existing extracurricular activities. The application of extracurricular management through four stages, namely planning, organizing, implementing, and monitoring. Whereas the results achieved include, the interest of santri in following extracurricular activities increases every year, the reduction in the number of violations of santri, self-development whose ultimate goal is the independence of santri can be seen through emotional, intellectual, social, and economic independence.

Keyword: Management, Extracurricular, Pesantren (Islamic Boarding School)

\section{PENDAHULUAN}

Pendidikan merupakan usaha manusia untuk membina kepribadiannya sesuai dengan nilai-nilai di dalam masyarakat dan kebudayaan. ${ }^{1}$ Dengan adanya pendidikan nilai-nilai luhur suatu bangsa bisa terawat melalui generasi penerusnya. Beragam para ahli mendefinisikan pendidikan itu berbeda-beda, Ki Hajar Dewantara mengatakan bahwa pendidikan merupakan proses menuntun segala kekuatan kodrat anak agar mereka sebagai manusia dan anggota masyarakat bisa mencapai keselamatan dan kebahagian yang setinggi-tingginya. Dalam konteks ke-Indonesiaan definisi Pendidikan salah satunya tertuang dalam UU Nomor 20 tahun 2003 tentang Sistem Pendidikan Nasional dengan maksud intinya mengembangkan potensi diri dan semua kekuatan yang dimiliki peserta didik.

Oleh sebab itu, Semua jenis lembaga pendidikan baik pendidikan formal, informal maupun nonformal harus mampu mewujudkan cita-cita luhur pendidikan tersebut. Pesantren merupakan salah satu lembaga

\footnotetext{
${ }^{1}$ Hasbullah, Dasar-dasar Ilmu Pendidikan, (Jakarta: Rajawali Pers, 2011),
} hal. 1. 
pendidikan nonformal yang ada di Indonesia. Kehadiran lembaga ini, sudah sejak lama menjadi maskot pendidikan Indonesia dalam membentuk watak dan peradaban bangsa serta mencerdaskan kehidupan bangsa yang berbasis pada keimanan serta akhlak mulia, jauh sebelum undang-undang tentang Pendidikan Nasional dicetuskan. Sejarah mencatat bahwa pondok pesantren merupakan lembaga pendidikan tertua yang ada di Indonesia. ${ }^{2}$

Namun fenomena pendidikan saat ini, khususnya pesantren masih dipandang sebelah mata oleh sebagian masyarkat. Pandangan sebagai lembaga konservatif, eksklusif dan bahkan anti-perubahan masih melekat dinisbatkan terhadap lembaga pendidikan tertua itu. ${ }^{3}$ Apalagi jika melihat pondok pesantren yang bertipologi salaf, kelemahan-kelemahan akan semakin jelas terlihat, seperti pengelolaan masih tradisional, praktik manajemen berjalan sederhana dan berpola pada kebiasaan yang telah berlaku, belum memiliki wirausaha permanen, serta hampir semua pesantren salaf milik individu dan tidak bisa ditekan oleh kekuatan lain sehingga tugas kiai mejadi multifungsi yaitu sebagai guru, mubalig sekaligus manajer. ${ }^{4}$

Mengembalikan marwah pondok pesantren kepada fungsi pokok yang sebenarnya harus segera diwujudkan. Terobosan yang bisa dilakukan oleh pondok pesantren dalam mengembalikan fungsi pokoknya salah satunya adalah memberikan kebebasan kepada para santri untuk mengembangkan talenta mereka masing-masing baik yang berkenaan dengan pemikiran, teknologi, kewirausahaan maupun olahraga. Dan menyediakan wahana akulturasi diri di tengah-tengah masyarakat. ${ }^{5}$ Terobosan-terobosan tersebut bisa termuat dalam kegiatan ekstrakurikuler. Program ekstrakurikuler sekiranya mampu di manfaatkan serius oleh pondok pesantren sebagai sarana pengembangan diri para santrinya, namun di

${ }^{2}$ Nur Efendi, Manajemen Perubahan di Pesantren,(Sleman: Kalimedia, 2016), cet. 1. Hal. 1

${ }^{3}$ Ainurrofiq Dawam dan Ahmad Ta'arifin, Manajemen Madrasah Berbasis Pesantren, (Yogyakarta: ListafariskaPutra, 2005), hal. 6

${ }^{4}$ Hamdan Farehan dan Syarifuddin, Titik Tengkar Pesantren Resolusi Konflik Pesantren, (Yogyakarta: Pilar Religia, 2005), hal. 68.

${ }^{5}$ Ibid., hal 70 . 
sebagian pondok pesantren khususnya yang bertipologi tradisional kegitan ekstrakurikuler belum menjadi sorotan utama dalam proses pengembangan diri santri.

Kehadiran ekstrakurikuler di pondok pesantren akan bisa mewadahi dalam proses perkembangan santri dalam tambahnya ilmu pengetahuan secara umum serta mengetahui potensi diri yang dimilikinya. Hal itu senada dengan kedudukan santri dalam Undang-undang nomor 20 Tahun 2003 pasal 1 ayat 4 adalah "Anggota masyarakat yang berusaha mengembangkan potensi diri melalui proses pembelajaran pada jalur pendidikan baik pendidikan informal, pendidikan formal, maupun pendidikan non formal, pada jenjang Pendidikan dan jenis Pendidikan tertentu". ${ }^{6}$ Peraturan tersebut juga sama dengan landasan pengembangan diri dalam pendidikan secara umum yaitu mengacu pada potensi. Sedangkan dalam konsep pendidikan Islam mengacu fitrah, yang mempunyai arti kekuatan asli yang yang terpendam di dalam diri manusia yang dibawa sejak lahir. ${ }^{7}$

Pondok Pesantren Salaf Al-luqmaniyyah merupakan pondok pesantren salaf putra dan putri yang mengkaji ilmu Islam dengan menggunakan sumber Al-Quran, Hadits dan kitab-kitab klasik. Pesantren Alluqmaniyyah yang berada di kecamatan Umbulharjo, kota Yogyakarta, Provinsi Daerah Istimewa Yogyakarta. Awal perkembangannya, jumlah siswa tidak lebih dari dua puluh orang. Pada saat itu, Pondok Pesantren AlLuqmaniyyah diperuntukan khusus bagi para santri yang ingin menuntut ilmu agama, tanpa menempuh pendidikan formal. Perlahan Paradigma tersebut mulai dirubah dengan menerima para santri yang juga menempuh pendidikan formal di berbagai sekolah atau universitas di Yogyakarta. Perubahan yang dibuat akhirnya membuahkan hasil, banyak para santri yang berdatangan. Tahun demi tahun pesantren ini mulai diminati oleh para siswa dengan tujuan untuk menuntut dan memperdalam ilmu agama. Hingga saat

\footnotetext{
${ }^{6}$ Anonim, Undang-Undang Republik Indonesia Tahun 2003 ..., hal. 4.

${ }^{7}$ Arifin I dan Slamet, Kepemimpinan Kyai dalam Perubahan Manajemen Pondok Pesantren;Kasus Ponpes Tebu Ireng Jombang, (Yogyakarta: Aditya Media, 2010)
} 
ini tercatat sekitar 380 santri yang mondok dengan mayoritas adalah mahasiswa perguruan tinggi di dalam wilayah Yogyakarta.

Pondok Pesantren Al-Luqmaniyyah mempunyai kegiatan ekstrakurikuler dalam mengakomodir minat dan bakat para santrinya. Kehadiran ekstrakurikuler menjadi perhatian serius para pengurus di Pesantren Al-Luqmaniyyah, sehingga membentuk sebuah bidang khusus untuk mengelola ekstarkurikuler yang ada. Penelitian mengenai manajemen ekstrakurikuler dalam ranah pendidikan pesantren menjadi hal yang sangat penting dilakukan, ekstrakurikuler sebagai sarana bagi santri dalam mengembangkan diri menjadi manusia seutuhnya. selain itu penelitian ini sebagai langkah awal dalam menciptakan pengelolaan lembaga pesantren yang lebih baik secara keseluruhan, dan manajemen ekstrakuirkuler secara khusus.

\section{METODE PENELITIAN}

Penelitian yang berjudul manajemen ekstrakurikuler dalam upaya pengembangan diri santri Pondok Pesantren Al-luqmaniyyah ini menggunakan jenis penelitian kualitatif deskriptif, karena dalam penelitian ini peneliti bermaksud mendeskripsikan dan menganalisi fenomena atau kegiatan dalam obyek tertentu. Metode kualitatif ini dilakukan sebagai prosedur penelitian dalam menghasilkan data deskriptif, yaitu data yang dihasilkan berupa kata-kata tertulis ataupun lisan dari objek yang diteliti. ${ }^{8}$ Adapun yang dimaksud dengan penelitian kualitatif adalah penelitian yang mendapatkan data dengan menggunakan latar alamiah dengan tujuan untuk menafsirkan fenomena yang terjadi dengan melibatkan berbagai metode yang ada. ${ }^{9}$ Hal ini menuntut peneliti sebagai insturmen inti dalam dalam mendapatkan data. Sumber data penelitian adalah tempat, orang atau responden sebagai sarana memperoleh informasi. Pemilihan informan dalam penelitian ini menggunakan teknik Purposive sampling (sampel bertujuan). Purposive adalah mereka yang menurut peneliti memiliki informasi yang

${ }^{8}$ Anis Fuad, Kadung Sapto Nugroho, Panduan Praktis Penelitian Kualitatif, (Yogyakarta:Graha Ilmu, 2014), hlm. 54.

${ }^{9}$ Lexy J. moleong, Metode Penelitian Kualitatif, (bandung: Rosda Karya, 2007), hlm.5. 
dibutuhkan dalam penelitian ini, dikarenakan dalam kesehariannya mereka selalu berusan dengan permasalah yang sedang diteliti. ${ }^{10}$

Teknik pengumpulan data yang digunakan peneliti dalam penelitian ini, yaitu metode observasi, wawancara, dan dokumentasi. Observasi dalam penelitian kualitatif adalah berbetuk narasi atau deskripsi dari hal-hal yang dilakukan subyek dalam kondisi alami (natural settings). Observasi yang peneliti laksanakan menggunakan observasi partisipatif yakni peneliti mengamati apa yang dikerjakan orang, mendengarkan apa yang mereka ucapkan dan berpartisipasi dalam aktivitas mereka dalam arti peneliti terlibat langsung dalam kegiatan sehari-hari orang yang sedang diamati. Wawancara mendalam (In-depth Interview) menjadi teknik yang peniliti gunakan karena dalam teknik ini peneliti bisa tanya jawab sambil bertatap muka dengan responden dan bisa terlibat langsung dalam kehidupan sosial dari responden dengan waktu yang relatif lama. Metode Dokumentasi adalah proses pengumpulan catatan harian, dokumen, dan administrasi yang relevan dengan masalah yang diteliti, sehingga diperoleh data sebagai penunjang penelitian. ${ }^{11}$

\section{HASIL DAN PEMBAHASAN}

\section{Konsep Manajemen Ekstrakurikuler Pondok Pesantren Al- Luqmaniyyah}

Tipologi pondok pesantren di Indonesia terbagi ke dalam tiga kategori, yaitu pesantren Salafiyah, pesantren Khalafiyah, dan pesantren Campuran/kombinasi. ${ }^{12}$ Apabila dilihat dari tipologi pondok pesantren tersebut Al-Luqmaniyyah merupakan salah satu pondok pesantren yang bertipologi pesantren Salafiyyah, dimana dalam menyelenggarakan pembelajarannya masih menggunakan sistem tradisional yaitu dengan metode sorogan dan bandongan serta berkonsentrasi pada kitab-kitab klasik. hlm. 218.

${ }^{10}$ Sugiyono, Metode Penelitian Administrasi,(Bandung : Alfabeta, 2008),

11 Suharsimi, arikunto, Prosedur Penelitian Suatu Pendekatan Praktik, (Jakarta: Rineka Cipta, 2013hlm. 206.

12 Departemen Agama RI, Pondok pesantren dan Madrasah Diniyah Pertumbuhan dan Perkembanagnnya, (Jakarta: Direktoral Jendral Kelembagaan Islam, 2003), hal.29. 
pesantren Al-Luqmaniyyah juga memiliki kegiatan ekstrakurikuler yang merupakan kegiatan tambahan di luar jam pelajaran dalam rangka mengembangkan potensi dan minat bakat yang dimiliki santri. Kemunculan ekstrakurikuler terjadi pada tahun 2006 dan terus berkembang sampai saat ini. Pada tahun 2014 keseriusan Pondok Pesantren Al-luqmaniyyah dalam mengurus ekstrakurikuler dibuktikan dengan berdirinya Departemen bidang Pengembangan Sumber Daya Santri (PSDS).

Tujuan lain dari keberadaan ekstrakurikuler di Pondok Pesantren AlLuqmaniyyah adalah agar santri bisa beraktivitas di dalam pondok. Dengan mayoritas santri adalah mahasiswa yang tentunya memiliki kegiatan yang begitu padat, tentunya menguras fikiran dan ingin mencari suasana serta kegiatan baru di luar pondok. Dengan adanya ekstrakurikuler bisa meminimalir santri melakukan kegiatan di luar pondok yang sebenarnya di dalam pondok juga ada. Jika melihat konsep adanya ekstrakurikuler yang dikembangkan oleh Pondok Pesantren Al-Luqmaniyyah sangat sesuai dengan salah satu tujuan umum berdirinya Pondok Pesantren yaitu untuk menyiapkan santri sebagai kader bangsa yang tangguh, memiliki keimanan dan ketaqwaan kepada Allah SWT, berakhlak mulia, terampil, dan beramal shaleh. Karena dengan santri yang memiliki kreatifitas tinggi serta memiliki keterampilan yang lebih bisa memudahkan mereka dalam menghadapi kehidupan di masyarakat kelak. Dan semua itu bisa tercapai salah satunya dengan adanya ekstrakurikuler di pondok pesantren. Dari pemaparan di atas dapat disimpulkan bahwa konsep kehadiran ekstrakurikuler adalah sebagai berikut:

Pertama, dibentuknya Bidang Pengembangan Sumber Daya Santri sebagai departemen untuk mengelola ekstrakurikuler di Pondok Pesantren Al-Luqmaniyyah, sehingga proses penyaluran minat dan bakat santri bisa terprogram dengan baik.

Kedua, dalam proses terbentuknya ekstrakurikuler di Pondok Pesantren Al-Luqmaniyyah berawal dari beberapa santri yang berkumpul membentuk sebuah komunitas kemudian setelah eksistensi komunitas 
tersebut terlihat maka pengurus Bidang Pengembangan Sumber Daya Santri mengukuhkannya sebagai sebuah ekstrakurikuler.

Ketiga, ekstrakurikuler yang dicetuskan pesantren Al-Luqmaniyyah bertujuan agar santri lebih banyak beraktivitas di lingkungan pesantren. Sehingga santri tidak mencari kegiatan-kegiatan yang berada di luar lingkungan pesantren yang bisa menyebabkan melanggar aturan pondok. Seperti meninggalkan mengaji dan tidak mujahadah.

Keempat, dalam proses kegiatannya, ekstrakurikuler tidak boleh menggangu kegiatan mengaji. Karena pada dasarnya, ekstrakurikuler adalah kegiatan tambahan yang mendukung kegiatan utama di Pondok Pesantren Al-Luqmaniyyah.

\section{Penerapan Manajemen Ekstrakurikuler di Pondok Pesantren Al- Luqmaniyyah}

Kegiatan ekstrakurikuler adalah kegiatan yang di lakukan dalam rangka pengembangan minat dan bakat di luar jam pelajaran. Kehadiran manajemen dapat mengelola sumber daya yang kita miliki, baik sumber daya manusia, materi, uang, metode dan yang lainnya untuk mencapai tujuan yang ditentukan secara efektif dan efisien. ${ }^{13}$ Manajemen ekstrakurikuler di Pondok Pesantren Al-Luqmaniyyah dapat dianalisa menggunakan berbagai pendekatan, namun peneliti melakukan analisa menggunakan teori George R. Terry yang menyebutkan bahwa Fungsi manajemen terdapat empat bagian yaitu, perencanaan, pengorganisasian, pelaksanaan, dan pengawasan. 14

\section{Perencanaan}

Perencanaan merupakan tindakan menetapakan terlebih dahulu apa yang diinginkan di masa yang akan datang. Dengan adanya rencana yang jelas, sehingga bisa memudahkan dalam proses pelaksanaannya. Ada tiga hal yang selalu berhubungan dalam proses pembuatan perencaan yaitu, perumusan tujuan yang ingin dicapai, pemilihan program untuk mencapai tujuan, dan pengerahan sumber daya.

13 Husaini Usman, Manajemen, teori Praktik dan Riset Pendidikan, (Jakarta: Bumi Aksara, 2006) hal. 2

${ }^{14}$ Nanang Fattah, Landasan Manajemen Pendidikan, (Bandung: Remaja Rosdakarya, 1996,) hal. 13. 
Perumusan Tujuan Ekstakurikuler,

Sebagaimana di paparkan sebelumnya dalam konsep ekstrakurikuler di Pondok Pesantren Al-luqmaniyyah, dari hasil wawancara penulis dengan narasumber, menyatakan bahwa rumusan tujuan ekstrakurikuler di $\mathrm{Al}$ Luqmaniyyah yaitu : Kehadiran ekstrakurikuler bertujuan sebagai sarana pengembangan minat dan bakat santri. Manusia diciptakan berbeda-beda dengan bakat yang berbeda-beda pula. Di Pondok pesantren AlLuqmaniyyah santri diperbolehkan berkreasi sesuka hati sesuai keinginan dan hobi mereka. ${ }^{15}$ Kehadiran ekstrakurikuler bertujuan agar para santri lebih banyak beraktivitas di dalam pondok. Sehingga kegiatan apapun yang ekstrakurikuler lakukan selama membuat para santri nyaman dan betah tinggal di dalam pondok itu yang akan pengurus pondok dukung dan meninggalkan kegiatan tambahan yang biasa mereka lakukan di luar pondok sebagai penyaluran minat dan bakatnya. ${ }^{16}$

Pemilihan Program untuk Mencapai Tujuan

Ekstrakurikuler yang ada di Pondok Pesanten Al Luqmaniyyah terdapat 11 jenis terbagi ke dalam 13 nama ekstrakurikuler. ${ }^{17}$ Pemilihan program ekstrakurikuler tersebut seluruhnya merupakan kegiatan yang diinginkan oleh santri dan dibuat oleh santri, pengurus pondok hanya mengukuhkan ekstra-ekstra yang diusulkan oleh santri dengan berbagai pertimbangan. Ekstrakulikuler tersebut adalah: ${ }^{18}$ Seni hadroh, LQ FC (Luqmaniyyah Football Club), LBC (LQ Beauty Club), English Club,

15 Hasil wawancara dengan Maskur Hamba, wakil ketua pusat bidang Pengembangan Sumber Daya Santri Pondok Pesantren Al-Luqmaniyyah pada Jumat, 15 juli 2017 di serambi masjid Pondok Al-Luqmaniyyah, pukul 00.05-00.30 WIB.

16 Kumpulan hasil wawancara dengan Romdhon M. Adi dan Masykur Hamba selaku ketua dan wakil ketua pusat bidang Pengembanagn Sumber Daya Santri Pondok Al-Luqmaniyyah pada tanggal 11-17 Juni 2017.

${ }^{17}$ Data dokumentasi soft file program kerja ketua ekstrakurikuler tahun 2016 kepada bidang Pengembangan Sumber Daya Santri pesantren AlLUqmaniyyah, diambil pada tanggal 30 Agustus 2017.

${ }^{18}$ Kumpulan hasil wawancara dengan M. Raka anantama dan Afifah Ikram selaku ketua PSDS komplek putra dan putri Pesantren Al-Luqmaniyyah pada kamis, 15 Juni 2017 sampai 29 juli 2017. 
Qolamuna ( Seni Kaligrafi), LQ Handy Craf (seni kerajinan tangan), Buletin, JQH (Jami'ah Quro' Wal Hufadz), Tilawah, LBM (Lajnah Bahtsul Masail), Arabic Club.

Dalam rangka mencapai tujuan yang diinginkan terutama agar minat dan bakat santri bisa terasah dan tentunya para santri tidak mencari kegiatan di luar pondok, dalam hal ini bidang Pengembangan Sumber Daya Santri menetapkan beberapa program diantaranya: ${ }^{19}$ Kegiatan Rutinan Mingguan, Dalam setiap minggunya PSDS memberi waktu dan tempat kepada setiap ekstrakurikuler untuk bisa menggelar latihan rutin mingguan. Kegiatan Bulanan, Setiap ekstrakurikuler bisa mengikuti event yang di selenggarakan oleh pihak luar baik itu swasta atau pemerintah. Dalam kaitannya dengan kegiatan bulanan ini tentunya tidak ada kepastian, karena belum tentu ada suatu perlombaan ataupun acara yang diselenggarakan. Kegiatan Tahunan, Pondok Pesantren Al-Luqmaniyyah memberi kebebasan bagi para santrinya untuk berkreasi sesuai minat dan bakat mereka masingmasing. Dalam hal ini PSDS membuat suatu rangkaian kegiatan yang diselenggarakan setiap tahunnya. Diantara program tahunan ekstrakurikuler di Pondok Pesantren Al-Luqmaniyyah adalah: Bulan Ekspresi Ekstra (BEE) merupakan bulan yang ditunggu-tunggu penggiat ekstra di Al-Luqmaniyyah. Dalam ajang ini, setiap ekstra diharuskan menyelenggarakan event ekstranya masing-masing. Kegiatan ini menjadi rutinan tahunan pada bulan Februari. ${ }^{20}$ Festival Hadroh antar Pondok Pesantren Se-DIY, Keberadaan hadroh di Pondok Pesantren Al-Luqmaniyyah merupakan elemen yang tidak bisa di pisahkan dari ciri khas pesantren. Ekstrakurikuler hadroh di AlLuqmaniyyah ada tim Hadroh Ababil untuk santri putra dan Hadroh Azkiya untuk santri putri. Untuk kegiatan festival Hadroh antar Pondok Pesantren Se-DIY menjadi program khusus dari PSDS. Melihat geliat perkembangan

${ }^{19}$ Kumpulan hasil wawancara dengan M. Raka anantama dan Afifah Ikram selaku ketua PSDS komplek putra dan putri Pesantren Al-Luqmaniyyah pada kamis, 15 Juni 2017 sampai 29 juli 2017.

${ }^{20}$ Kumpulan hasil wawancara dengan M. Raka anantama dan Afifah Ikram selaku ketua PSDS komplek putra dan putri Pesantren Al-Luqmaniyyah pada kamis, 15 Juni 2017 sampai 29 juli 2017. 
hadroh di daerah Yogyakarta yang semakin ramai, maka PSDS mengambil bagian dengan adanya festival hadroh antar pondok Pesantren Se-DIY bisa mempererat silaturahmi antar pondok serta sebagai ajang promosi dari Pondok Pesantren Al-Luqmaniyyah itu sendiri. ${ }^{21}$ Turnamen Futsal Antar Santri, Kegiatan ini sebagai bagian acara dalam memperingati hari lahir Pondok Pesantren Al-Luqmaniyyah. Dalam prosesnya, kegiatan ini diikuti oleh beberapa pondok pesantren yang ada di lingkup provinsi Yogyakarta. Menentukan Sumber Daya yang Diinginkan

Pada tahun penerimaan santri baru, Pondok Pesantren AlLuqmaniyyah mengadakan kegiatan Masa Orientasi Santri Baru (MOSBA) sebagai wahana bagi santri dalam mengenal lebih jauh tentang AlLuqmaniyyah, dalam event ini PSDS juga melakukan perannya untuk mempromosikan ekstra-ekstra yang ada di Al-Luqmaniyyah, juga sekaligus perekrutan anggota baru. ${ }^{22}$ Pelaksanaan kegiatan ekstrakurikuler di Pondok Pesantren Al-Luqmaniyyah tidak hanya terfokus di area pondok pesantren saja, dikarenakan fasilitas yang masih kurang lengkap, sehingga sebagian kegiatan ekstra menggunakan fasiltas yang ada di luar pondok. ${ }^{23}$ Bidang Pengembangan Sumber Daya Santri menetukan waktu pelaksanaan kegiatan ekstrakurikuler agar tidak menggangu kegiatan pokok yang ada di Pondok. Pemilihan waktu mayoritas disepakati adalah hari sabtu dan minggu. Pemilihan waktu tersebut dikarenakan mayoritas santri adalah mahasiswa maka pada hari-hari tersebut biasanya santri tidak memiliki jadwal perkuliahan di kampusnya masing-masing dan juga pada hari tersebut biasanya santri mencari kegiatan lain di luar pondok pesantren. Berikut

${ }^{21}$ Hasil wawancara dengan M. Raka anantama ketua PSDS komplek putra Pesantren Al-Luqmaniyyah pada kamis, 15 Juni 2017 di Kantor komplek putra pada pukul 19.39-20.03 WIB.

${ }^{22}$ Hasil wawancara dengan M. Raka anantama ketua PSDS komplek putra Pesantren Al-Luqmaniyyah pada kamis, 15 Juni 2017 di Kantor komplek putra pada pukul 19.39-20.03 WIB.

${ }^{23}$ Kumpulan hasil wawancara dengan M. Raka anantama dan Afifah Ikram selaku ketua PSDS komplek putra dan putri Pesantren Al-Luqmaniyyah pada kamis, 15 Juni 2017 sampai 29 juli 2017. 
jadwal waktu dan tempat pelaksanaan kegiatan ekstra yang ada di Pondok Pesantren Al-Luqmaniyyah

Dana merupakan salah satu aspek yang sangat penting berjalannya suatu ekstra. Pondok Pesantren Al-Luqmaniyyah mengelontorkan dana agar ekstrakurikuler yang ada dapat melaksanakan kegiatannya. Setiap ekstra mendapatkan pendanaan yang berbeda-beda satu sama lainnya, tergantung kebutuhan dan keperluan mereka dalam melaksanakan kegiatan. Anggaran ekstrakurikuler tersebut diambil dari APBP (Anggaran Pendapatan dan Belanja Pesantren) yang telah ditetapakan pada rapat anggaran dana. Berikut adalah anggaran dana ekstrakurikuler di Al-Luqmaniyyah:

Anggaran dana ekstrakurikuler Pondok Pesantren Al-Luqmaniyyah tahun $2017^{24}$

\begin{tabular}{|c|c|c|}
\hline No & Ekstra & Anggaran perbulan \\
\hline 1 & Hadroh ababil & Rp 70.000 \\
\hline 2 & LQFC & Rp 70.000 \\
\hline 3 & Qolamuna & Rp 100.000 \\
\hline 4 & English Club & $\begin{array}{ll}\mathrm{Rp} & 70.000\end{array}$ \\
\hline 5 & Lajnah Bahtsul Masail & Rp 70.000 \\
\hline 6 & Buletin Iqra & Rp 170.000 \\
\hline 7 & Hadroh Azkiya & Rp $\quad 30.000$ \\
\hline 8 & LQ Handy Craff & $\begin{array}{ll}\mathrm{Rp} & 90.000\end{array}$ \\
\hline 9 & LQ Beauty Club & Rp $\quad 30.000$ \\
\hline 10 & Buletin An-Najwa & Rp 170.000 \\
\hline 11 & Jami'ah Quro Wal Hufadz & Rp. 150.000 \\
\hline 12 & Tilawah & Rp 170.000 \\
\hline 13 & Arabic Club & $\begin{array}{ll}\mathrm{Rp} & 30.000\end{array}$ \\
\hline
\end{tabular}

Berdasarkan pemaparan di atas terkait perencanaan kegiatan ekstrakurikuler di Pondok Pesantren Al-Luqmaniyyah yang di dalamnya memuat perumusan tujuan ekstrakurikuler, pemilihan jenis program

24 Hasil wawancara dengan Afifah Ikram, koordinator bidang Pengembangan Sumber Daya Santri komplek putri Pondok Pesantren AlLuqmaniyyah pada sabtu, 29 Juli 2017 tempat kantor pusat Al-Luqmaniyyah pukul 10.55-11.34 WIB. 
ekstrakurikuler dan penentuan sumber daya yang akan digunakan dalam kegiatan ekstrakurikuler. Sementara literatur yang peneliti baca bahwa perencanaan harus memuat minimal tiga tahapan yaitu perumusan tujuan yang ingin dicapai, pemilihan program untuk mencapai tujuan dan pengerahan sumber daya, maka menurut peneliti perencanaan yang yang dibuat oleh Pengembangan Sumber Daya Santri di Pondok Pesantren AlLuqmaniyyah sesuai dengan literature dikarenakan memuat tiga tahap perencanaan tersebut.

\section{Pengorganisasian}

Pengorganisasian ekstrakurikuler di Pondok Pesantren AlLuqmaniyyah cukup tertata rapi, hal terlihat dari struktur kepengurusan serta pemberian tugas terhadap bidang Pengembangan Sumber Daya Santri dalam membina ekstra-ekstra yang ada untuk mencapai tujuan yang ditetapkan. Berikut ini adalah struktur organisasi bidang Pengembangan Sumber Daya Santri Pondok Pesantren Al-Luqmaniyyah:

Susunan Organisasi bidang Pengembangan Sumber Daya Santri Pondok Pesantren Al-Luqmaniyyah terdiri dari Ketua pusat pengembangan sumber daya santri, wakil ketua pusat pengembangan sumber daya santri, pengembangan sumber daya santri komplek putra, pengembangan sumber daya santri komplek putri, dan ekstrakurikuler.

Berdasarkan tabel di atas dapat dijelaskan bahwa tugas kepala dan wakil kepala pusat bidang PSDS Pondok Pesantren Al-luqmaniyyah yaitu Menggali dan mengembangkan kreatifitas santri, Bertanggung jawab terhadap hidup dan matinya kegiatan ekstra pondok Sedangkan pada PSDS ditingkat komplek proses pembagian tugas semakin rinci, Setiap anggota PSDS ditugaskan untuk membimbing dan mendampingi ekstra yang telah ditentukan

\section{Pelaksanaan}

Dalam proses pelaksanaan ekstrakurikuler di Pondok Pesantren AlLuqmaniyyah peran Pengembangan Sumber Daya Santri komplek sangat penting dalam menggerakan seluruh ekstrakurikuler untuk bekerja dengan 
sendiri dan penuh kesadaran dalam mencapai tujuan yang diinginkan. Dalam proses melaksanakan tugasnya yang telah di tetapkan pada tahap perencanaan, PSDS komplek melaksanakan tugasnya melalui beberapa kegiatan:

Pelaksanaan Kegitan Mingguan

Kegiatan rutinan mingguan merupakan kegiatan yang harus dilaksanaan oleh ekstra-ekstra yang ada di Pesantren Al-Luqmaniyyah, setiap ekstra di dampingi oleh anggota PSDS. Selain itu dalam proses pelaksanaannya anggota PSDS memberi motivasi dan semangat kepada setiap ketua ekstrakurikuler agar bisa istiqomah dalam menjalankan program-program yang mereka susun. Berikut ini adalah salah satu gambar dari kegiatan rutinan mingguan ekstrakurikuler di Pondok Pesantren AlLuqmaniyyah.

Pelaksanaan Kegiatan Bulanan

Kegiatan bulanan merupakan kegiatan kondisional dari setiap ekstra yang ada di Pondok Pesantren Al-Luqmaniyyah, karena kegiatan ini menunggu adanya event yang di selenggarakan oleh pihak luar dan hal ini belum pasti ada setiap bulannya. Dalam pelaksanaannya PSDS ditugaskan mendampingi dan memenuhi seluruh kebutuhan anggota ekstra yang sedang mengikuti suatu perlombaan. ${ }^{25}$

Pelaksanaan Kegiatan Tahunan

Kegiatan tahunan yang diselenggarakan oleh Bidang PSDS pesantren Al-Luqmaniyyah terdiri dari Bulan Ekspresi Ekstra, Festival Hadroh Antar Pondok Pesantren se-DIY, dan Turnamen Futsal Santri Antar Pondok Pesantren Se-DIY. Peran PSDS dalam pelaksanaan event-event tersebut yaitu membantu panitia pelaksana kegiatan.

Dari data yang diperoleh di atas apabila kita membandingkan dengan teori yang dikemukan oleh George $\mathrm{R}$ Terry bahwa pelaksanaan

${ }^{25}$ Hasil wawancara dengan M. Raka anantama ketua PSDS komplek putra Pesantren Al-Luqmaniyyah pada kamis, 15 Juni 2017 di Kantor komplek putra pada pukul 19.39-20.03 WIB. 
merupakan usaha untuk menggerakan anggota-anggota kelompok sedemikian rupa sehingga mereka berkeinginan dan berusaha untuk mencapai sasaran perusahaan dan sasaran anggota perusahaan tersebut. ${ }^{26}$ Sedangkan dalam proses pelaksanaan ekstrakurikuler yang ada di Pondok Pesantren Al-Luqmaniyyah peran bidang Pengembangan Sumber Daya Santri sangat penting dalam memberikan motivasi, dan menggerakan ketua ekstrakurikuler disetiap kegiatannya, baik kegiatan mingguan, bulanan dan tahunan. Sehingga roda kegiatan setiap ekstra dapat berjalan baik.

\section{Pengawasan}

Untuk menjamin keterlaksanaan program ekstrakurikuler, bidang Pengembangan Sumber Daya Santri Pondok Pesantren Al-Luqmaniyyah melakukan pengawasan. Yaitu, Pengawasan langsung dilakukan pada saat program ekstrakurikuler berlangsung, anggota PSDS yang bertugas mendampingi kegiatan ekstra setiap minggunya, juga bertugas mengawasi keberlangsungan program ekstra tersebut. ${ }^{27}$ Pengawasan tidak langsung adalah pengawasan jarak jauh. Pengawasan ini dilakukan melalui hasil laporan dari anggota baik laporan lisan, tulisan dan laporan khusus. ${ }^{28}$ PSDS melakukan kumpulan setiap bulannya bersama seluruh ketua ekstrakurikuler yang ada di Pondok Pesantren Al-Luqmaniyyah. Dengan adanya kegiatan ini akan diperoleh data-data berupa keluhan dan keadaan ekstranya dari setiap ketua ekstra baik aspek kemajuan maupun hambatan yang dilalui oleh ekstrakurikuler setiap bulannya, sehingga dijadikan bahan evaluasi untuk pengambilan keputusan dimasa yang akan datang.

Apabila melihat hasil data yang diperoleh dari lapangan bahwa pengawasan yang dilakukan oleh bidang Pengembangan Sumber Daya

${ }^{26}$ Nanang Fattah, Landasan Manajemen Pendidikan, (Bandung: Remaja Rosdakarya, 1996), hal. 72.

27 Hasil wawancara dengan Afifah Ikram, koordinator bidang Pengembangan Sumber Daya Santri komplek putri Pondok Pesantren AlLuqmaniyyah pada sabtu, 29 Juli 2017 tempat kantor pusat Al-Luqmaniyyah pukul 10.55-11.34.

${ }^{28}$ Usman Efendi, Asas Manajemen, (Jakarta: Rajawali Pers, 2014), Hal. 208. 
Santri Pesantren Al-Luqmaniyyah menggunkan dua cara yaitu pengawasan langsung dengan melibatkakan anggota PSDS sebagai pengawas dalam kegiatan rutinan ekstra, dan pengawasan tidak langsung dilakukan dengan pertemuan satu bulan sekali dengan seluruh elemen ekstrakurikuler.

\section{Pengembangan Diri Santri Pondok Pesantren Al-Luqmaniyyah}

Pengembangan diri adalah proses pembentukan sikap dan prilaku yang relatif menetap melalui pengalaman yang berulang-ulang sampai pada tahap otonomi (kemandirian) mengenai suatu prilaku tertentu. Selain itu, pengembangan diri bertujuan untuk menunjang pendidikan peserta didik dalam mengembangkan minat, bakat, kreativitas, kompetensi dan kebiasaan dalam kehidupan keagamaan, kemampuan sosial, kemampuan belajar, wawasan dan perencanaan karir, kemampuan pemecahan masalah dan kemandirian. ${ }^{29}$ Sehingga pengalaman dan pengetahuan yang berulang-ulang akan membawa santri pada tahap kemandirian, baik kemandirian emosi, ekonomi, intelektual, sosial. ${ }^{30}$ Proses pengembangan diri di Pondok Pesantren Al-Luqmaniyyah menghasilkan beberapa hal dalam diri santri. Semua dampak pengembangan diri itu meliputi kemandirian yang di dalamnya memuat kemandirian emosi, ekonomi, intelektual, sosial maupun tujuan pengembangan diri sebagai penunjang pendidikan peserta didik secara tersirat bisa terlihat melalui hasil yang peroleh ekstrakurikuler berupa output maupun outcome.

Output dari pengembangan diri santri adalah hasil langsung dan segera dari kegiatan ekstrakurikuler yang dilakukan oleh Pesantren AlLuqmaniyyah. Output ini bisa dilihat dari input santri yang awalnya tidak mempunyai keahlian tetapi setelah masuk dan mengikuti kegiatan ekstrakurikuler mereka akhirnya memiliki kemampuan yang berguna bagi diri sendiri dan menjadi bekal kelak di kehidupan masyarakat, salah satu output adalah prestasi yang diraih beberapa bidang ekstrakurikuler. Berikut

${ }^{29}$ Departemen Agama, Pedoman Kegiatan Pengembangan Diri, (Jakarta : 2005), Hal. 5

30 Desmita, Psikologi Perkembangan Peserta Didik, (Bandung: Rosdakarya, 2009), hal. 186. 
adalah output berupa prestasi santri yang dihasilkan oleh beberapa ekstrakurikuler Pondok Pesantren Al-Luqmaniyyah :

Perolehan prestasi ekstrakurikuler

Pesantren Al-Luqmaniyyah tahun $2017^{31}$

\begin{tabular}{|c|c|c|c|}
\hline Nama ekstra & Tahun & Jenis kegiatan & Prestasi \\
\hline \multirow[t]{2}{*}{ Hadroh Ababil } & 2016 & $\begin{array}{l}\text { Festival seni \& Hadroh } \\
\text { Majlis Pemuda Islam } \\
\text { Indonesia Bantul }\end{array}$ & Juara I \\
\hline & 2016 & $\begin{array}{l}\text { Festival Hadroh Se- } \\
\text { DIY \& Jawa Tengah }\end{array}$ & Juara II \\
\hline \multirow[t]{2}{*}{ LQFC } & 2016 & $\begin{array}{l}\text { Turnamen Futsal Antar } \\
\text { Santri Se-DIY }\end{array}$ & Semifinal dan Top Skor \\
\hline & 2017 & Nurma Cup & $\begin{array}{l}\text { Semifinal dan Suporter } \\
\text { terbaik }\end{array}$ \\
\hline $\begin{array}{l}\text { Buletin } \\
\text { Annajwa }\end{array}$ & 2017 & $\begin{array}{l}\text { Write For Feace } \\
\text { bersama Lutfi JW }\end{array}$ & $\begin{array}{l}\text { Penyelenggara dan } \\
\text { peserta }\end{array}$ \\
\hline \multirow[t]{3}{*}{ LQ Handy Craf } & 2017 & $\begin{array}{l}\text { Pelatihan pemanfaatan } \\
\text { barang bekas di Posko } \\
\text { KKN }\end{array}$ & Pemateri \\
\hline & 2017 & $\begin{array}{l}\text { Pelatihan pemanfaatan } \\
\text { barang bekas di Posko } \\
\text { KKN }\end{array}$ & Pemateri \\
\hline & 2017 & $\begin{array}{l}\text { Tamu Undangan di } \\
\text { Suka TV dalam acara } \\
\text { Inovasi Muda }\end{array}$ & Pemateri \\
\hline \multirow{2}{*}{$\begin{array}{l}\text { Hadroh } \\
\text { Azkiyya }\end{array}$} & 2016 & $\begin{array}{l}\text { Festival Seni Hadroh } \\
\text { Al-Ukhuwah } \\
\text { Maguwoharjo } 2016\end{array}$ & Juara Kostum Terbaik \\
\hline & 2017 & $\begin{array}{lr}\text { Festival Hadroh dalam } \\
\text { Rangka } & \text { Harlah } \\
\text { Universitas } & \text { Islam } \\
\text { Indonesia } & \\
\end{array}$ & Peserta \\
\hline Buletin Iqra & 2017 & $\begin{array}{lr}\text { Lomba Cerpen } & \text { Santri } \\
\text { Nasional } & 2017 \\
\text { CSSMORA UIN Sunan } \\
\text { Kalijaga }\end{array}$ & $\begin{array}{l}\text { kategori } 20 \text { Naskah } \\
\text { Terbaik }\end{array}$ \\
\hline
\end{tabular}

Dari tabel di atas dapat kita pahami bahwa prestasi ekstrakurikuler di tahun 2016-2017 cukup baik untuk sekelas pondok pesantren Salaf, meskipun prestasi yang didapat tidak merata diperoleh oleh seluruh ekstrakurikuler yang ada di pesantren Al-Luqmaniyyah. Karena memang tujuan dan fungsi awal dari keberadaan ekstrakurikuler di Pesantren AlLuqmaniyyah adalah sebagai alat penyalur minat dan bakat santri. Sedangkan outcome ekstrakurikuler Pondok Pesantren Al-Luqmaniyyah adalah hasil efek jangka panjang berupa dampak, manfaat dari proses

31 Dokumentasi data prestasi ekstrakurikuler bidang Pengembangan Sumber Daya santri tahun 2016-2017. 
kegiatan ekstrakurikuler. Berdasarkan hasil penelusuran peneliti ada beberapa outcome yang dihasilkan dari ekstrakurikuler antara lain ekstrakurikuler hadroh putra Ababil, ekstra ini kerap menjadi bintang tamu dalam suatu kegiatan misalnya acara khitanan, aqiqah dan nikahan. ${ }^{32}$ Sehingga ekstra ini bisa menghasilkan keuntungan dari hasil pentas tersebut.

Ada juga LQ Handy Craft, ekstra ini mampu mendatangkan keuntungan dari produk yang mereka hasilkan melalui pemanfaatan barang bekas, selain itu kerap kali ekstra LQ Handy Craf menjadi pemateri dalam sebuah pelatihan sehingga mendapatkan upah dari jasa tersebut. Melalui lulusannya sebuah program bisa dilihat seberapa jauh dampak dan manfaatnya hasil dari kegiatan program tersebut. Hasil dari ekstrakurikuler di Pondok Pesantren Al-Luqmaniyyah adalah menciptakan lulusan ekstra yang mampu bersaing di dunia kerja dan bermanfaat di masyarakat. Diantara alumninya adalah ada yang bergerak dibidang jasa pembuatan souvenir pernikahan, box bunga, kado wisuda, dan lain-lain. Wirausaha ini bernama Twiny Craft, dirintis oleh dua orang santri kembar, mereka adalah alumni ekstrakurikuler LQ Handy Caft. Karya tangan ini dijual dari kisaran harga Rp 15.000- 200.000..$^{33}$ Mereka adalah lulusan dari ekstra Qolamuna Pondok Pesantren Al-Luqmaniyyah. Dalam sekali pekerjaan mereka mendapatkan imbalan sekitar satu juta. ${ }^{34}$

\section{KESIMPULAN}

Berdasarkan analisis data pelaksanaan ekstrakurikuler dalam upaya pengembangan diri santri di Pondok Pesantren Al-Luqmaniyyah Yogyakarta, maka peneliti menarik simpulan bahwa Konsep ekstrakurikuler yang dikembangkan oleh Pondok Pesantren Al-Luqmaniyyah adalah sebagai

32 Hasil wawancara dengan M. Raka anantama selaku ketua PSDS komplek putra Pesantren Al-Luqmaniyyah pada kamis, 15 Juni 2017 di Kantor komplek putra pada pukul 19.39-20.03 WIB.

${ }^{33}$ Hasil wawancara dengan Neneng Suryani putri alumni ekstra LQ Handy Craft pada tanggal 18 Oktober 2017, pukul 09.00 WIB.

34 Hasil wawancara dengan Dimas Mahaputra alumni ekstra Qolamuna pada tanggal 18 Oktober 2017 pukul 10.00 WIB. 
wadah pengembangan diri bagi santri, sehingga santri bisa mengembangkat minat dan bakat yang dimilikinya. Lahirnya bidang Pengembangan Sumber Daya Santri (PSDS) menjadi vital dalam tugas mengatur seluruh ekstrakurikuler di pesantren Al-Luqmaniyyah. Penerapan manajemen ekstrakurikuler di Pondok Pesantren Al-Luqmaniyyah Yogyakarta telah sesuai dengan fungsi-fungsi manajemen yang ada meliputi pertama perencanaan, dilakukan melalui proses perumusan tujuan ekstrakurikuler, Pemilihan program ekstra, dan penentuan sumber daya yang akan digunakan. Kedua pengorganisasian, dengan memberikan tugas kepada bidang Pengembangan Sumber Daya Santri untuk mengelola ekstra. Ketiga pelaksanaan, kegiatan ekstrakurikuler yang telah ditetapkan dengan jadwal kegiatan rutinan mingguan, bulanan dan tahunan. Keempat pengawasan, dimana dalam setiap kegiatan ekstrakurikuler PSDS akan menilai bahwa pelaksanaan benar-benar sesuai dengan perencanan, dan mengkoreksi penyimpangan untuk perbaikan dimasa yang akan datang. Yang keempat fungsi tersebut telah di maksimalkan oleh bidang Pengembangan Sumber Daya Santri. Hasil dari kegiatan ekstrakurikuler di Pondok Pesantren AlLuqmaniyyah dapat dilihat dari jumlah yang mengikuti ekstrakurikuler setiap tahunnya yang terus bertambah. Sedangkan hasil dari pengembangan diri dapat dilihat melalui output dan outcome kegiatan ekstrakurikuler. Output ekstrakurikuker mengasilkan santri memiliki skill lebih setelah mengikuti ekstra, sedangkan outcome bisa dilihat dari beberapa lulusannya yang bisa berwirausaha dengan skill yang didapatnya dari kegiatan ekstra, seperti ada lulusan yang menjadi guru ekstra hadroh disekolah formal, membuat kerajinan tangan, jasa pembuatan kaligrafi masjid.

\section{REFERENSI}

Agama, Departemen Pedoman Kegiatan Pengembangan Diri, Jakarta : 2005. arikunto, Suharsimi, Prosedur Penelitian Suatu Pendekatan Praktik, Jakarta: Rineka Cipta, 2013.

Dawam, Ainurrofiq dan Ahmad Ta'arifin, Manajemen Madrasah Berbasis Pesantren, Yogyakarta: ListafariskaPutra, 2005.

Depag Direktorat Jendral Kelembagaan Agama Islam, Panduan Kegiatan Ekstrakurikuler Pendidikan Agama Islam, Jakarta, 2005. 
Desmita, Psikologi Perkembangan Peserta Didik, Bandung: Rosdakarya, 2009.

Dhofier, Zamakhsyri Tradisi Pesantren Studi Tentang Padangan Hidup Kyai, Jakarta : LP3ES, 2013.

Efendi, Nur Manajemen Perubahan di Pesantren, Sleman: Kalimedia, 2016.

Efendi, Usman, Asas Manajemen, Jakarta: Rajawali Pers, 2014

Farehan, Hamdan dan Syarifuddin, Titik Tengkar Pesantren Resolusi Konflik Pesantren, Yogyakarta: Pilar Religia, 2005.

Fattah, Nanang Landasan Manajemen Pendidikan, Bandung: Remaja Rosdakarya, 1996.

Fuad, Anis dan Kadung Sapto Nugroho, Panduan Praktis Penelitian Kualitatif, Yogyakarta:Graha Ilmu, 2014.

Halim, A. Dkk, Manajemen pesantren, Yogyakarta: Lkis, 2005.

Hasbullah, Dasar-dasar Ilmu Pendidikan, Jakarta: Rajawali Pers, 2011.

I, Arifin dan Slamet, Kepemimpinan Kyai dalam Perubahan

Manajemen Pondok Pesantren;Kasus Ponpes Tebu Ireng Jombang, Yogyakarta: Aditya Media, 2010

Moleong, Lexy J, Metode Penelitian Kualitatif, bandung: Rosda Karya, 2007.

Muahaimin, dkk, Pengembangan Model Kurikulum Tingkat Satuan

Pendidikan pada Sekolah dan Madrasah, Jakarta: Raja Grafindo Persada, 2010.

Nasir, M. Ridlwan Mencari Tipologi Format pendidikan Ideal Pondok Pesantren di Tengah Arus Perubahan, Yogyakarta: Pustaka Pelajar, 2010

Nugroho, Anis Fuad, Kadung Sapto, Panduan Praktis Penelitian Kualitatif, Yogyakarta: Graha Ilmu, 2014.

RI, Departemen Agama, Pondok pesantren dan Madrasah Diniyah Pertumbuhan dan Perkembanagnnya, Jakarta: Direktoral Jendral Kelembagaan Islam, 2003.

Sugiyono, Metode Penelitian Administrasi,Bandung : Alfabeta, 2008.

Sulistryorini, Manajemen Pendidikan Islam, Yogyakarta: Teras, 2009.

Usman, Husaini, Manajemen , Teori, Praktik dan Riset Pendidikan, Jakarta: Bumi Aksara, 2006. 